\title{
CASHING IN ON LAND AND PRIVILEGE FOR THE WELFARE OF THE SHAH: MONETISATION OF TIYŪL IN EARLY SAFAVID IRAN AND EASTERN ANATOLIA*
}

\author{
KIOUMARS GHEREGHLOU \\ Columbia University, Center for Iranian Studies \\ 450 Riverside Drive, New York, NY 10027, USA \\ e-mail:kg2458@columbia.edu
}

\begin{abstract}
The assignment of land as tiyūl to early Safavid military and bureaucratic elites was conditional on their emoluments being subjected to direct taxation on annual basis. Between 914 and 918/1508 and 1512, the money-based disposal of tiy $\bar{u} l$ land assignments boosted Shah Ismā'îl's control over fiscal resources in Iran. In the province of Diyarbakir, however, the Safavid practice of tiyūl expedited dynastic transition, enabling the new regime to uproot the regional allies and partners of the Aqquyunlu. A glimpse at monetisation of tiyzul brings necessary torch into the dynamics of bureaucratic centralisation and its political implications in this early phase of territorial expansion and political absolutism in the Safavid history. The principal primary source this study explores is an unpublished fiscal statement, kept as document E. 1071 at the Topkap1 Palace Museum Archives in Istanbul, that details the taxes paid to central treasury by early Safavid tiyūl-holders in Iran and eastern Anatolia over the course of four fiscal years (914-918/1508-1512).
\end{abstract}

Key words: Tiyūl, fiscal administration, direct taxation, Shah Ismā‘ $َ 1$ l, Diyarbakir, Iran, Safavids, Qizilbāsh.

\section{Introduction}

Studies on early modern systems of land tenure have drawn our attention to the limits of central government's control over the fiscal and administrative status quo across the rural and urban settlements temporarily assigned to bureaucratic and military elites. Fiscal evaluation and direct taxation were two principal procedures that were

* I would like to thank John E. Woods of the University of Chicago for sharing with me his copy and partial transcription of document E. 1071. I am also indebted to Vural Genç who kindly offered to send me the digitised copy of two evrak pieces of archive as well as a copy of his forthcoming article on the Ottoman plunder of the Hasht Bihisht Gardens in Tabriz in 920/1514. 
applied to ensure the centralised management of land and cash revenues in early modern polities. In the Ottoman Empire, the timmār districts were subject to occasional cadastral land surveys, making their bestowal and/or renewal dependent upon fluctuations in taxpayer population statistics (Beldiceanu 1980, pp. 46-48; Howard 1987, pp. 7-11; Tezcan 2010, p. 20; Bartusis 2013, pp. 580-581). Basically, the early Safavid practice of tiy $\bar{u} l$ - the most common type of short-term land assignment in early modern Iran - was similar to the Ottoman military timmār in that both authorised the assignee to collect and invest the local annual tax yields on drafting and training a pre-determined number of cavalry forces. ${ }^{1}$ Known as täbīn or recruits in Persian bureaucratic terminology, the army units thus raised and organised by tiy $\bar{u} l$-holders were required to be called up and deployed at short notice in times of general mobilisation or $j \bar{a} r$ u yas $\bar{a} q$ side by side with the regiments under the command of the shah. The 15th-century tiy $\bar{u} l$-holders had to attend an almost identical set of responsibilities (Ṭihrānī 1962-1964, pp. 371, 571).

Unlike the Ottoman timār -holders, whose career mobility was contingent on the state's approval of their fiscal management in provinces, tiy $\bar{u}$-holders in Safavid Iran had to pay a portion of their emoluments to the royal treasury to make their way up on the rungs of political ladder. During the 16th and 17th centuries, a similar situation shaped power relations between the king and the landed men-at-arms in France, whose revenues from land and privilege were subjected to direct taxation in the form of imposts such as taille, octroi, don gratuit, and crue levies (Beik 1985, pp. 245251; Collins 1988, pp. 45-48; Goldstone 1991, pp. 212-213). Even in the Ottoman Empire, in remote provinces such as Egypt, Baghdad, and Yemen, where the administrative hold of the state was no concrete, timmăr-holders paid a pre-determined percentage of their annual revenues to central treasury (Inalcik et al. 1994, Vol. 1, p. 73).

Vladimir Minorsky, Il'ia P. Petrushevskii, Ann K. S. Lambton, and Bert Fragner pioneered the study of tiyūl under the Safavids. Minorsky (1927, p. 800; [Mīrzā Samī ā] 1943, pp. 28-29) and Lambton (1991, p. 110; 2000, p. 550) considered it respectively as "financial expedient" and "land assignment made to officials in lieu of salary", implying that by parceling out administrative districts as tiyy $\bar{u}$ among the military and bureaucratic elites the central authorities sought a leeway to dodge their fiscal and administrative responsibilities to the institutionally less manageable provincial sector of the bureaucracy. This line of argument represents tiy $\bar{u} l$ as the Safavid equivalent of the Ottoman practice of temlik $k$, according to which the grantee enjoyed absolute and hereditary rights and privileges "within a virtually autonomous enclave within the territory of the state" (Inalcik 2006, p. 112). Never going beyond overgen-

\footnotetext{
${ }^{1}$ According to 16 th- and 17 th-century tiyūl-nāma appointment letters, besides commanding military forces in provinces, the Safavid tiy $\bar{u} l$-holders acted as provincial dīvān begīs, supervising the execution of criminal justice. Homicide was the only crime they had not been allowed to deal with as it was supposed to be taken to religious courts; see, for instance, documents IX (Dhu'lQa'da 991/November-December 1583), XII (Sha‘ban 996/June-July 1588), XV (Dhu'l-Hijja 999/September-October 1591), XVI (Jumada I 999/March-April 1591), and XXX (Dhu'l-Hijja 1036/September 1627) in Puturidze (1955, pp. 19, 33-34, 39, 41-42, 73-74); on the post of dīvān begī, see Floor (2000, pp. 20-21).
} 
eralising on tiyūl as practised under the later Safavids, it leaves us in the dark over how tiy $\bar{u} l$ and $t i y \bar{u} l$-holders operated under the early Safavids. Instead of the first Safavid century, as the temporal scope to explore the practice of tiy $\bar{u} l$ within its framework, both Minorsky and Lambton tended to focus on the trends and events in the 17 th century and afterwards, an era punctuated by the relatively long intervals of efficiency crisis at court and political instability in provinces. This shift in temporal scope is crucial as since the opening quarter of the 17 th century, the Safavid central bureaucracy ceased to deal out tiy $\bar{u} l$ land assignments on a non-hereditary basis. ${ }^{2}$

Expanding on the conclusions drawn by Minorsky and Lambton, Fragner (1986, p. 516) argued that as practised under the Safavids, tiyül was a continuation, albeit in a smaller scale and more simplified manner, of mediaeval $i q t \bar{a}^{\prime}$ as well as the post-Ilkhanid practice of söyürghāl: all three entailed the devolution of land and power into the hands of the forces of decentralism. ${ }^{3}$ It is true that in times of political unrest and bureaucratic stagnation at the centre tiy $\bar{u} l$ could give strength to centrifugal tendencies in the periphery. Yet Petrushevskii (1949, pp. 188-189) put stress on the centralising potentialities of the practice in early Safavid Iran, highlighting the fact that the scheduled assignment of tiy $\bar{u} l$ helped the central government incentivise land and privilege in favour of more "servile" servitors of the throne.

The contractual nature of the practice of tiysul under the early Safavids provided for the central government to perpetuate its presence on the horizon of administrative life in provinces. To keep this system of administrative control and fiscal centralisation working, the shah needed to make tiy $\bar{u} l$-holders accountable for their exploitation of tax resources in provinces. If there was any effective mechanism of fiscal and administrative control that might have kept them in check it was direct taxation. Direct taxation on early Safavid tiyūl-holders provided for the Shah Ismā'îl's fledgling government to experiment with a centralist platform of administrative evaluation and reward as a viable alternative to the intrinsically decentralist Turko-Mongol practices of corporate and confederative exploitation of land operative in Iran and Central Asia during the 15 th and 16 th centuries. ${ }^{4}$ Under Shah Ismā'īl (1501-1524), almost all tiyūl-holders were required to deposit a portion of their emolument with the royal treasury. Over the course of the 16th and 17th centuries, düshlik (the amounts a tiyül-holder had to pay upon arrival at the court) in particular and rusüm or pre-determined imposts in general were the two principal categories of the fees the grand vizier's office or daftarkhānayi humāyūn collected from tiy $\bar{u} l$-holders across the country on behalf of the shah. ${ }^{5}$

${ }^{2}$ In 1026/1617 Shah 'Abbās ordered all in-office tiyūl-holders to take over the control of their land grants on a permanent and hereditary basis; see AFT III, f. 383r. Thus, no accident that in the last two thirds of the 17 th century and beyond tiy $\bar{u} l$ was known to be a type of "perpetual" land grant; see Chardin (1811, Vol. 5, pp. 416-417); cf. Kaempfer (1712, Vol. 1, p. 97).

${ }^{3}$ Similarly, the parliamentary bill that proposed the abolition of tiy $\bar{u} l$ in 1907 claimed that the administrative decentralism of the country under the Safavids and their successors rooted in the practice of tiyūl; see Lambton (1987, p. 74); cf. Sharīf (1352 Sh./1973, pp. 79-85).

${ }^{4}$ For more on corporate and confederative exploitation of land, see Dickson (1963); Woods (1999, p. 20); Subtelny (2007, pp. 36-38).

${ }^{5}$ On düshlik and rusūm, see Nașīrī (1371 Sh./1992, p. 8); Anșārī Iṣfahānī (1380 Sh./2001, p. 540); cf. Doerfer (1963-1975, Vol. 3, pp. 211-214). 
The earliest recorded attempt to impose direct taxation on tiyūl-holders in Iran is datable to about a century prior to Shah Ismā 'îl's rise to power. A late 15 th-century Timurid chronicler described the procedure as tas 'itr or "price enforcement", a judicial move normally carried out against misdeeds such as monopoly and price-fixing conspiracies. ${ }^{6}$ The episode on extracting tas ${ }^{i} \mathrm{r}$ fees from Timurid military chiefs contains the earliest known mention of the practice of tiy $\bar{u} l$ in Persian historiography, given sub anno 810/1407-1408. In that year, a Herat-based Timurid vizier is reported to have demanded the tiyūl-holders posted to eastern Iran and Central Asia to pay cash to get their land assignments renewed by the court. By so doing, it is pointed out, the central authorities sought to defray the debts the tiyūl-holders had incurred at the expense of the royal treasury in the wake of Tamerlane's death. In the short run, this first bid to monetise tiyül through direct taxation proved destabilising as it prompted the delinquent tiy $\bar{u} l$-holders to plot a regicide and, when it failed, to muster their troops and take arms against the newly enthroned Timurid ruler Shāhrukh (807-850/14051447) (Samarqandī 1935-1939, Vol. 2, Pt. 1, p. 63).

This article studies re-monetisation of tiyȳl under Shah Ismāâil (907-930/15011524) over the course of four fiscal years (914-918/1508-1512) and the way in which it shaped administrative centralisation and dynastic transition in Iran and eastern Anatolia. This study argues that while in Iran the money-based disposal of tiyzul assignments smoothed the way for regularised income redistribution among the Qizilbāsh, in eastern Anatolia the monetisation of tiy $\bar{u} l$ was a catalyst for a radically absolutist agenda of dynastic transition that undid the Kurdish ruling families of Diyarbakir, leaving the Qizilbāsh with almost no allies in the region in the years leading up to the Ottoman invasion of Azerbaijan in 920/1514 and subsequent annexation of Diyarbakir in $922 / 1516$. The principal primary source this present study explores is an unpublished income statement prepared around 919/1512-1513. This statement provides us with rare statistical information on the shah's share of the income from direct taxation on the tiy $\bar{u} l$-holders posted to several dozen urban and rural districts in Iran and eastern Anatolia between 913/1507-1508 and 919/1512-1513.

\section{Evrak 1071: Provenance, Structure, and Chronology}

A potentially unique copy of the transcript version ( $s a v \bar{a} d$ ) of the unpublished income statement this present article draws on is housed at the Topkap1 Palace Museum Archives in Istanbul catalogued as Evrak 1071 or E. 1071. The document is in Persian and consists of four folios, which are likely to have originally been bound together as part of a miscellaneous collection or majmu $\bar{u}^{\prime} a{ }^{7}$ Composed in a cursive $t a{ }^{\prime} \bar{l} q$ script, the text is split throughout into two columns, except for the folios $1 \mathrm{r}$ and $4 \mathrm{v}$. Based

${ }^{6}$ Mainstream Shī'ite jurists consider tas 'ìr unlawful; see Țūsī (1387-1391 AH/1968-1972, Vol. 1, p. 195); Hiillī (1410 AH/1989-1990, Vol. 2, pp. 515-516); cf. Muntaziirī (1365 Sh./1986, p. 65).

${ }^{7}$ For two brief references in modern scholarship to E. 1071, see Bacqué-Grammont (1993, p. 16); and Woods (1999, p. 12). 
on its format and calligraphic style, E. 1071 has the appearance of a number of the late Aqquyunlu royal edicts and state documents. ${ }^{8} \mathrm{Ta}$ ' $\mathrm{l} \bar{q} q$ was one of the most popular scripts among the early Safavid bureaucrats. According to an early 17th-century biographical dictionary on calligraphers and painters (Husaynī Qumī 1359 Sh./1980, pp. 46-47; Husaynī Qumī 1959, pp. 87-88), some of the high-ranking bureaucrats at the court of Shah Ismā'îl mastered the script, including his vakil/vizier or deputy in fiscal/scribal affairs the Ni'mat-Allāhī mystique Zahīr al-Dīn Mīr 'Abd al-Bāqī Kūhbanānī Kirmān̄ī (d. 920/1514). ${ }^{9}$ The last date mentioned in E. 1071 coincided with the first year of Kirmān̄̄'s appointment as vizier, making it likely to assume that either he or one of his bureaucratic underlings must have prepared the transcript version of this income statement based on the original copy of the document as filed and archived at grand vizier's office.

E. 1071 has two parts, which altogether consist of seven sections. The first part details the shah's share of the income (sahm al-mulk-i humāyūn) from the imposts collected from the tiy $\bar{u} l$-holders shifted to more than eighty urban and rural districts in nine provinces. The document then closes with a brief list of the amounts made by the military chiefs who had received pay vouchers (barāt) in 916/1510-1511. E. 1071 consolidates four sets of data. First come the dates, all given in accordance with the turki fiscal/animal calendar. Then follow topographical details on the districts enfeoffed as tiyūl with the Qizilbāsh and non-Qizilbāsh military and bureaucratic elites in the provinces of Diyarbakir, Azerbaijan, Persian Iraq, Arabian Iraq, the Kalhur District, Fars, Luristan (Khurramabad) and Qara-Ulus, Kirman, and Khurasan. Almost all tiyūl-holders are identified by name, but some lack tribal nisba, making it difficult for the reader to ascertain their background based on narrative sources. The last set of data specifies the amount of the taxes collected from each tiyül-holder over the course of a six-year period, of which two years are listed as empty $(k h \bar{a} l \vec{\imath})$. In addition to the payments recorded under each tiy $\bar{u} l$ district, E. 1071 includes the aggregate amounts of the taxes paid by tiyül-holders per year and per province. An inverted exclamation mark stands next to each unit of topographical, prosopographical, and monetary data to set it apart from the next one.

The Ottomans must have seized E. 1071 during Selim I's invasion of Azerbaijan and subsequent sack of the shah's palace in Tabriz in the summer of 920/1514. ${ }^{10}$

\footnotetext{
${ }^{8}$ My comparison here is based on grey-scale duplicates of the documents XX, XXI, XXII, XXV, and XXVI in Ṭabātabā'̄' (1352 Sh./1973, pp. 87-106, 112-116, and 118-123). These documents are issued by the Aqquyunlu Sultan Ya'qūb (1478-1491), prince Qāsim b. Jahāngīr, and prince Alvand, respectively on 20 Dhu'l-Qa'da 891/17 November 1484, 4 Jumada I 892/28 April 1487, 7 Dhu'l-Qa‘da 893/13 October 1488, 5 Sha'ban 903/25 June 1498, and 14 Rajab 904/25 February 1499 . One of them, i.e. the edict dated 25 June 1498, has originally been published elsewhere; see Minorsky (1939, pp. 927-960). See also the facsimile copy of another Aqquyunlu document signed by Uzun Hasan (1457-1478) on $1 \mathrm{Rabi}^{`}$ I 877/6 August 1472, reproduced as Planch VI/document E. 3132 in volume one of Öz (1938-1940).

${ }^{9}$ On Kirmānī’s career under Shah Ismā‘īl, see AFT I, ff. 199 v-200r.

${ }^{10}$ For more on this incident, see Simões (1898, p. 244); Lütfi Paşa (1341 AH/1923, p. 237); Tekindağ (1968, p. 72); Hoca Sa'dettin Efendi (1979, Vol. 4, p. 218); Şükrî Bitlisî (1997, p. 184); Emecen (2011, p. 148).
} 
The plunder was orderly and systematic, at the end of which the looters prepared a detailed report itemising the confiscated belongings of the shah. Dated 12 Rajab 920/2 September 1514, the report thus drafted includes, in two parts, a long list of the items removed from the royal palace and the office of the court minister (mihtar$k h \bar{a} n a)$ at the Hasht Bihisht Gardens in Tabriz. The first part, which is at the Topkap1 Palace Museum Archives in the form of a small-size notebook bearing shelf number Defter 10734 or D. 10734, makes a reference to "some worn-out fiscal ledgers" or daftarhä-yi kuhna, which at some point after their transfer to Istanbul were to be detached from their spines so that their contents could be classified and archived separately as documents or evrak. Perhaps E. 1071 was part of one of these displaced and much-handed fiscal ledgers, a guess that can be made considering the still visible perforation marks on the gutter area of the first two folios of the document.

Table 1. E. 1071 Chronology

\begin{tabular}{lllcc}
\hline Annals & AH/AD Years & Turkī Years & Vernal Equinox (Nawrüz) & Regnal Years \\
\hline I & $913(1507-1508)$ & Dragon (Löy) & 9 Dhu'l-Qa'da (11 March) & 6 \\
II & $914(1508-1509)$ & Snake (Yilān) & 20 Dhu'l-Qa'da (12 March) & 7 \\
III & $915(1509-1510)$ & Horse (Yunt) & 1 Dhu'l-Hijja (12 March) & 8 \\
IV & $916(1510-1511)$ & Sheep (Q̈̈y) & 12 Dhu'l-Hijja (12 March) & 9 \\
V & $917-918(1511-1512)$ & Monkey (Pichīn) & 22 Dhu'l-Hijja (11 March) & $10-11$ \\
VI & $919(1512-1513)$ & Cock (Tavkhaqöy) & 3 Muharram (11 March) & 12 \\
\hline
\end{tabular}

Beginning with Year of the Dragon (Löy Yil), the dates given in E. 1071 are fiscal (see Table 1). The Tārīkh-i jahān-ärāa, a general history on pre-Islamic and Islamic dynasties of Iran by Aḥmad Ghaffărī Qazvīnī (d. after 972/1565), is the only 16th-century narrative source that has based its account on the reign of Shah Ismā'îl on the turk $\bar{l}$ fiscal/animal calendar. Two other Safavid chroniclers, who wrote their histories in the first part of the next century, also rely on the fiscal/animal calendar when dealing with the reign of the first Safavid monarch. But an interval of more than a century between them and Shah Ismā‘̄il made their chronological calculations go awry. While one of them tagged 917/1511-1512 as Year of the Dragon (Husaynī Qumī 1383 Sh./2004, p. 94), according to the other, Year of the Dragon coincided with 915/1510 (AFT I, f. 192r). Au contraire, Year of the Dragon under Shah Ismā‘̄ìl, as Ghaffārī Qazvīnī (1343 Sh./1964, p. 270) put it, first occurred in the sixth regnal year, i.e. the hijri//lunar year 913 (6 June 1507 to 1 May 1508). As the first day of this fiscal/animal year, the vernal equinox or Nawrüz was celebrated on the tail end of the hijrī/lunar year on 9 Dhu'l-Qa'da 913/11 March 1508, making the fiscal/animal year extend well into the next hijri//lunar year. That under 916/1510-1511, the year that ended with Shah Ismā‘̄il's conquest of Khurasan, ${ }^{11}$ E. 1071 lists the taxes collected

\footnotetext{
${ }^{11}$ On the conquest of Khurasan, see Khvāndmīr (1333 Sh./1954, Vol. 4, pp. 508-514); Szuppe (1992, pp. 77-78); Dūghlāt (1996, Vol. 1, p. 201); Amīn̄̄ Haravī (1383 Sh./2004, pp. 335-350). 
from the tiyūl-holders posted to the province bears out the accuracy of Ghaffärī Qazvinī's use of fiscal/animal calendar. Furthermore, there is archival evidence to corroborate his designation of the hijrī/lunar year 913/1507-1508 as Year of the Dragon. Dated Jumada I 910/October-November 1504, a certified affidavit signed by an anonymous Safavid bureaucrat, wherein he endorses the ownership of part of the land estates in the fortress town of Maku, some 155 miles to the northwest of Tabriz, by an Armenian priest and his descendants, confirms that 909/1503-1504 was Year of the Rat or Sìchqān Yil. ${ }^{12}$ In the turki fiscal/animal calendar, Year of the Rat precedes Year of the Dragon by four solar years.

Year of the Cock (Tavkhaqöy Yil), during which the vernal equinox occurred on 3 Muharram 919/11 March 1512 (Ghaffārī Qazvīnī 1343 Sh./1964, p. 275), is the last fiscal/animal year mentioned in E. 1071. A chronological anomaly sub anno 917-918 (31 March 1511 to 11 March 1513) makes the hijrï/lunar year 918/15121513 ten days shorter than a full Nawrüz cycle. Therefore, the amounts taxed and recorded during this particular fiscal year pertain to two hijrī/lunar years.

\section{Tiyūl Tax Flows}

Between the fiscal years 914 and 918/1508-1512 the Safavid tiyūl-holders generated an overall amount of 730 tümāns and 4000 dinars for the shah. More than half (56\%) of this amount had been contributed by the tiy $\bar{u}$-holders posted to the provinces of Diyarbakir, Azerbaijan, and Persian Iraq ('Irāq-i 'ajam). During these four fiscal years, direct taxation on tiy $\bar{u} l$-holders in these three provinces was year-by-year. During the same period, their counterparts in Arabian Iraq (Baghdad), Fars, Kirman, the Kalhur District (Kirmanshah), Luristan (and Qara-Ulus), and Khurasan had only occasionally paid their taxes to the royal treasury in Tabriz. However, the monetary value of these occasional payments did often outweigh the cash extracted more regularly from tiyūl-holders in Diyarbakir, Azerbaijan, and Persian Iraq (see Chart 1).

In addition to tiy $\bar{u} l$-holders, the military chiefs who had received pay vouchers also had to pay a portion of their annual emoluments to the shah. In the 16th century, these pay vouchers or barāts were normally issued early in autumn and authorised their bearers to procure for free or reduced prices the fodder ('ulüfa) and foodstuffs they and their retainers needed during the coming winter (Düghlāt 1996, Vol. 1, p. 218). In 916/1510-1511, Shah Ismā‘îl had made an overall amount of 75 tūmāns and 8000 dinars out of the barāt pay vouchers issued in the name of the military chiefs who had taken up residence in Khurasan subsequent to the invasion of Marv and Herat. When added to the amounts collected from tiy $\bar{u} l$-holders between 914 and 918/1508 and 1512, this last lump sum made the shah's share of the income from tiy $\bar{u} l$ land assignments and barāt pay vouchers add up to 800 tūmāns in a four-year period.

\footnotetext{
${ }^{12}$ See document XII/Planch XII in Papazian (1956-1968, Vol. 2, pp. 459, 564). For further evidence on 909/1503-1504 being Year of the Rat, see Ghaffärī Qazvīnī (1343 Sh./1964, p. 268); Nuvīīi Shīrāzī (1369 Sh./1990, p. 42); Ḥusaynī Qumī (1383 Sh./2004, p. 80).
} 


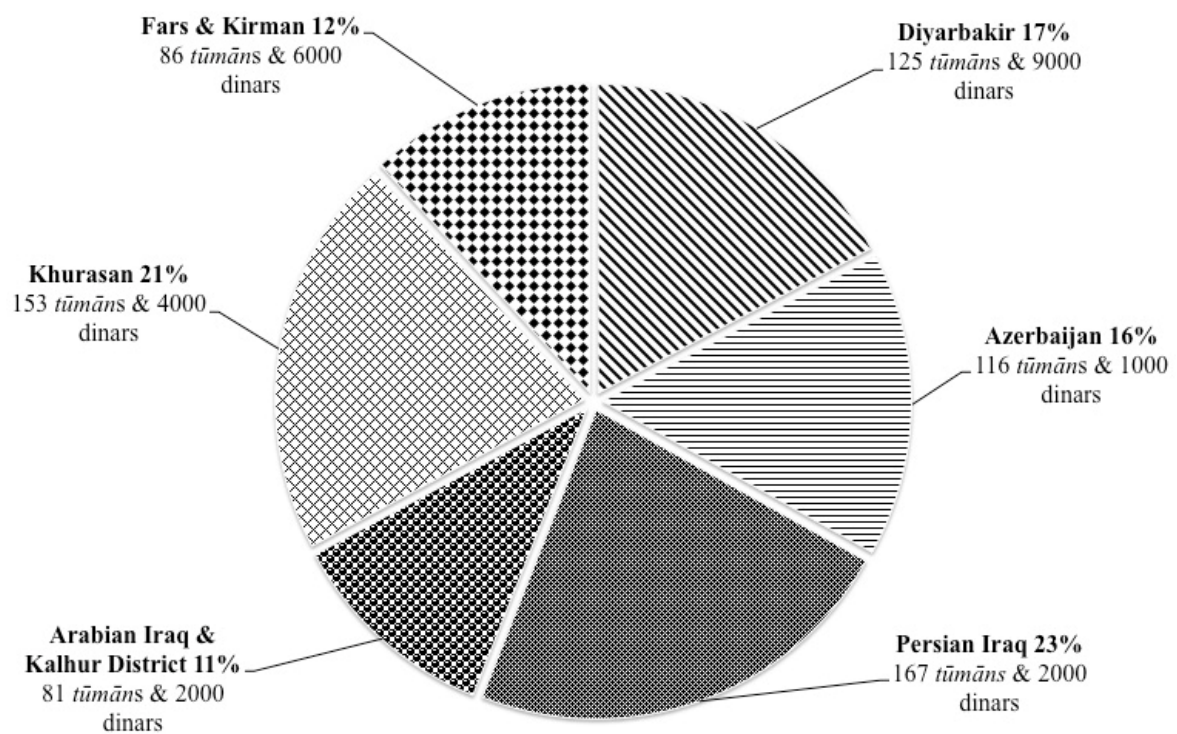

Chart 1. The shah's share of the income from tiyül land assignments per province, 1508-1512

How much of a tiyzul-holder's emolument was taxed during the reign of Shah Ismā $\overline{1} 1$ l? At present, there is no definite answer to this question. Late Safavid administrative manuals delineate the fiscal regulations (dastür al-'amal) concerning the rate of the taxes to be collected from tiyunl-holders, ${ }^{13}$ but these regulations deal with the fiscal practice in early 18th-century Iran and as such has nothing to do with the lay of the land under Shah Ismā‘îl. The earliest known set of fiscal regulations on the subject of direct taxation on tiy $\bar{u}$ l-holders in Safavid Iran dates from the opening decade of the 17th century. According to these regulations, each tiyül-holder was required to pay $3 \%$ of his annual emolument to the royal treasury in addition to the following fees:

(a) Ten percent of the cash value of the gifts (pishkash) presented to him by the local notables in each fiscal year;

(b) Five percent of the cash value of the benefactions (in 'amm) made to him by the shah;

(c) One percent of the amounts disbursed as annual salary among his retainers;

(d) Five percent of the annual tax yields of the tiyül district to which the tiyūlholder had been posted, to be collected as haqq al-qarār or appointment fees (Jung 3455, f. 168r). ${ }^{14}$

There is strong circumstantial evidence to suggest that under Shah Ismā' ${ }^{\circ} 1$ the taxes collected from tiy $\bar{u}$-holders amounted to a small fraction of their annual emolument - perhaps between 3 and 10\%. Each year, direct taxation on tiy $\bar{u} l$-holders gener-

${ }^{13}$ For instance, one administrative manual lists fourteen types of imposts and taxes collected from late Safavid tiyūl-holders; see [Mīrzā Samī‘āa] (1943, f. 42v); Nașīīi (1371 Sh./1992, p. 10).

${ }^{14}$ On this manuscript, see Hāà'irī (1348 Sh./1969-1970, Vol. 10, Pt. 3, pp. 1334-1385). 
ated an amount in the range of 100 to 150 tūmāns for central treasury. Except for the fiscal year 916/1510-1511, during which the military campaign against the Uzbek confederate clans had brought about a sharp rise in the rate of the taxes levied on tiy $\bar{u} l$ holders, the cash payments made by them did rarely exceed 15 tümāns in one fiscal year. Late in the $1500 \mathrm{~s}$, a payment of $15 t \bar{u} m \bar{a} n \mathrm{~s}$ was equal to the annual tax yield of three small-size rural settlements. According to a royal edict issued on 10 Rajab $915 / 24$ October 1509 , the annual tax yield of Kazaj, a minor rural district some 30 miles to the southwest of Khalkhal, had officially been assessed to be four tūmāns and 5000 dinars. $^{15}$ In 916/1510-1511, the Safavid bureaucrats had evaluated the annual emolument of the tiyül-holder posted to the town of Qa'in in Khurasan to be about 150 tümāns, and we know that in the same year the Qizilbāsh military governor of Qa'in had paid 13 tūmāns and 4000 dinars or less than $9 \%$ of his emolument to central treasury (E. 12212). The sharp debasement of the coinage in the latter part of the 15th century notwithstanding, under Shah Ismā'īl the monetary unit tūmān (10,000 dinars) in

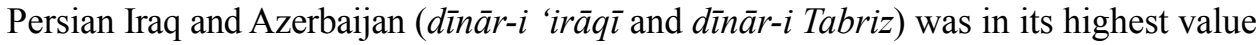
versus gold in the 16th century (Rabino 1945, p. 13; Fragner 1986, pp. 559-561).

How much of the royal treasury's revenues did come from direct taxation on tiyu $\bar{l}$-holders? It is safe to assume that the amounts collected from tiyül-holders constituted only a small fraction of the royal treasury's annual cash flow. In 916/15101511 , the cash accrued in central treasury at the end of two fiscal years is reported to have amounted to 20,000 tūmāns (Khvāndmīr 1954, Vol. 4, p. 491; Amīnī Haravī 2004, p. 313; cf. Simões 1898, p. 243), implying that direct taxation on tiyūl-holders over the course of four fiscal years had produced an amount on a par with less than $1 \%$ of the sum total of shah's revenues in one fiscal year.

The shah had made the most out of direct taxation on tiy $\bar{u} l$-holders in the fiscal

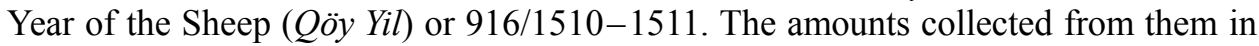
this year totaled 330 tūmāns and 9000 dinars (see Chart 2). This rise stemmed from the Safavid invasion of Khurasan, where more than fifteen rural and urban settlements were to be assigned at once as tiyūl to the Qizilbāsh military chiefs after Shah Ismā'īl's conquest of Marv and Herat in Sha'ban-Ramadan 916/November-December 1510. These newly appointed tiy $\bar{u} l$-holders had been recruited to shoulder part of the costs of the military campaign in Khurasan. In the next fiscal year, i.e. 917-918/1511-1513 or Year of the Monkey (Pichīn Yil), the amounts collected from tiyül-holders across the country dropped to 202 tūmāns and 4000 dinars. As we have seen above, fiscal extractions from tiyül-holders in Year of the Monkey covered two hijrī/lunar years and as such they seem to have been collected at once late in 916/1510-1511. The combined payments made in the fiscal Year of the Monkey kept the shah's share of the income from direct taxation on tiyūl-holders in the range of 100 tümāns per hijrì/lunar year.

The most productive tiy $\bar{u} l$-holders had been posted to Persian Iraq, where between 914-918/1508-1512 fourteen urban and rural settlements were administered as

\footnotetext{
${ }^{15}$ See document II in Martin (1965, pp. 180-181). Around the same time, a well-bred horse is reported to come in 30 tümāns in Persian Iraq, indicating that the shah's share of the income from direct taxation on $t i y \bar{u} l$-holders during a four-year period allowed him to procure only twelve to fifteen such horses for the royal cavalry regiments; see Amīnī Haravī (1383 Sh./2004, p. 362).
} 


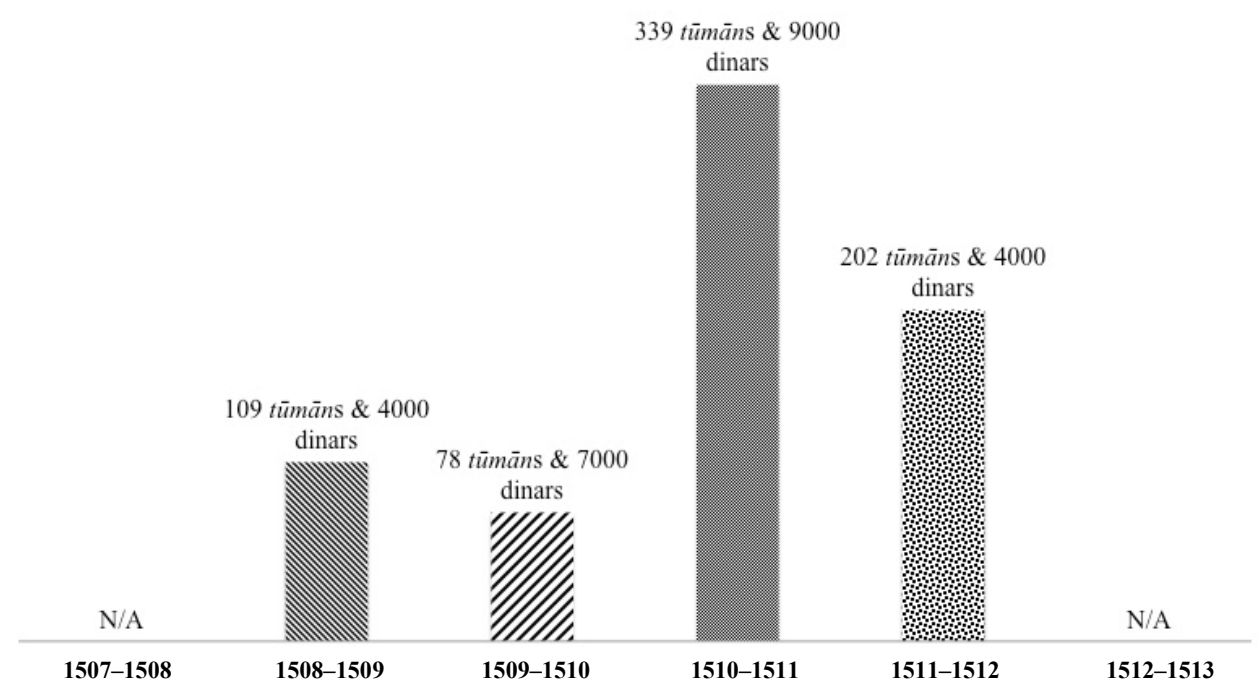

Chart 2. The shah's share of the income from tiyül land assignments per year, 1508-1512

Table 2. Taxes collected from tiȳūl-holders in Persian Iraq

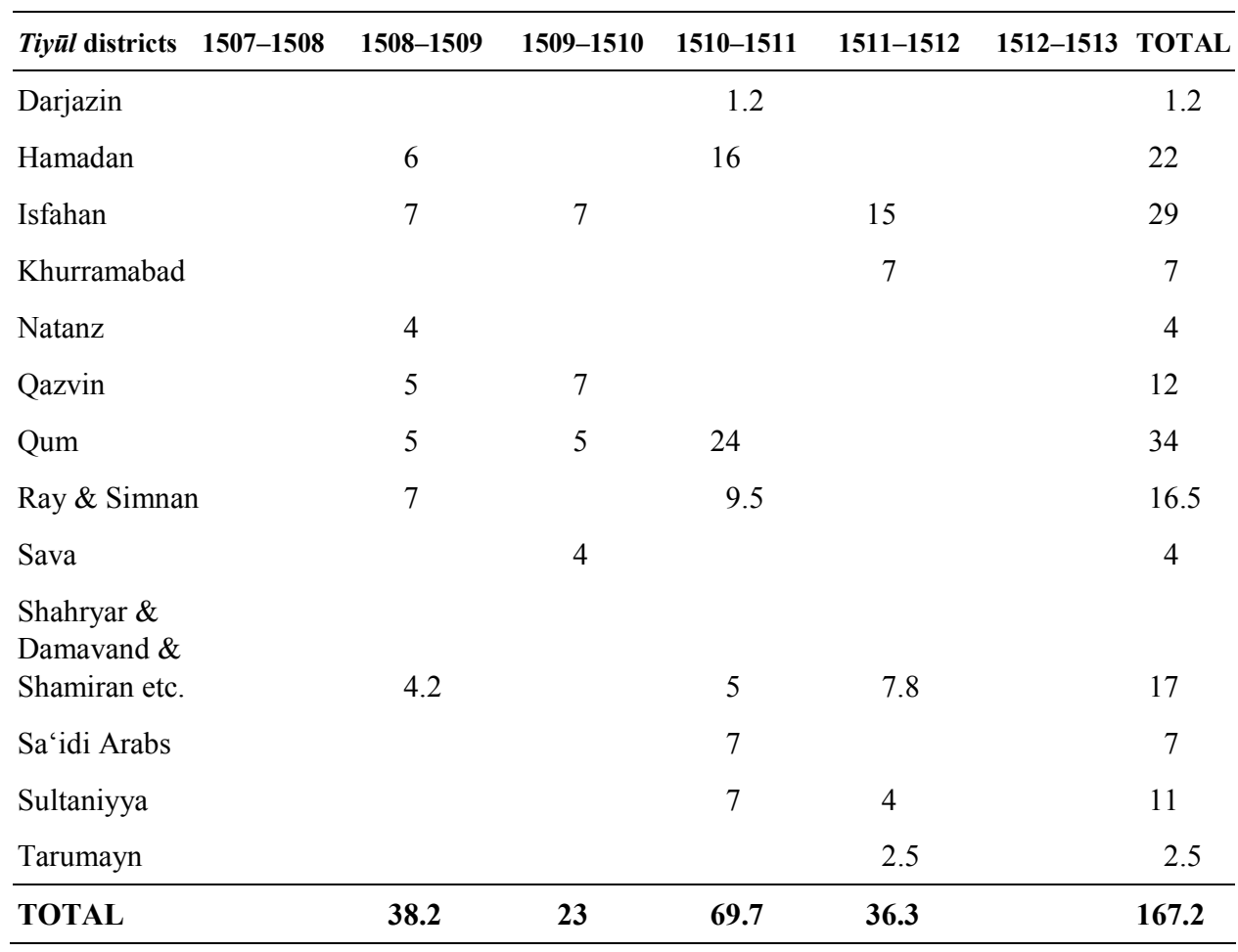

Acta Orient. Hung. 68, 2015 
tiyūl (see Table 2). Overall they had made a total of 167 tümāns and 2000 dinars for the shah during these four fiscal years. Under normal conditions, central treasury had levied the biggest amount of taxes (38 tümāns and 2000 dinars) on the tiy $\bar{u} l$-holdersposted to Persian Iraq in the fiscal Year of the Snake (Yilän Yil) or 914/1508-1509. As was the case with the rest of the country, Year of the Sheep or 916/1510-1511 saw a rise of more than 30 tummans in the amount of the taxes collected from tiyyul-holders in Persian Iraq, which obviously was due to the outbreak of wars with the Uzbeks and the central government's starving for cash in the wake of the conquest of Khurasan. The taxes collected from tiy $\bar{u} l$-holders in Persian Iraq amounted respectively to 23 tūmāns and 36 tümāns and 3000 dinars in 915/1509-1510 and 917-918/1511-1513.

Martin B. Dickson (1958, p. 38) considered Shah Ismā‘îl's invasion of Khurasan in 916/1510-1511 as no more than a war of prestige that ended with the conquest of "an area that was essentially extraneous to a power based on Iraq and Azerbayjan". But the remarkably large amount of the cash funneled through the monetisation of tiy ül land assignments in the province, which in the same year totaled 153 tümanns and 4000 dinars, calls into question the explanatory relevance of this observation. In the fiscal statement that details the shah's share of the income from tiy $\bar{u} l$ land assignments between 913 and 919/1507 and 1513, Khurasan shows up only once under the fiscal Year of the Sheep or the hijri/llunar year at the end of which the Safavids defeated the Uzbek Shībānī Khan (d. 916/1510) in Marv. That during one single fiscal year tiy $\bar{u} l$-holders in Khurasan had made more than one fifth (21\%) of the shah's share of the income from the taxes placed on all tiy $\bar{u} l$-holders in Iran and eastern Anatolia in a four-year period shows the conquest economy in full gear (see Table 3). To this substantial amount must be added the imposts levied on barāt-holders in Khurasan in the same fiscal year, which had provided the shah with a sum total of 75 tümāns, making his monetary profits from Khurasan rise to more than 414 tümāns in one fiscal year. Most of the tiyūl districts in Khurasan at the time of the Qizilbāsh conquest of the province were dominantly Sunni-populated. Perhaps the conquerors had subjected these Sunni Muslims to excessive taxation, hence the unusually higher rates of their cash contributions to central treasury. Be that as it may, tiy $\bar{u} l$-holders in Khurasan had made more money for the shah simply because of the fact that the brevity of their tenure in the province made it practically impossible for many of them to spend the bulk of local tax yields on recruiting and training täbin forces, a situation that made it possible for central authorities to require them to pay more cash. Under the remaining two fiscal years included in the statement in question there is no mention of Khurasan, implying that by the end of 917/1511-1512 the Safavid tiyül-holders had left the province. On 15 Rajab 917/918 October 1511, Shah Ismā'īl appointed the Timurid prince Bābur (d. 937/1530) as the governor of Khurasan. Bābur's period in Khurasan lasted only eight months until Rabi“ I 918/May-June 1512, when the Uzbeks invaded Samarqand, forcing him to flee to the south, first to Kunduz and then to Kabul (Dūghlāt 1996, Vol. 1, pp. 208, 217). As such, the amounts collected from tiyül-holders in Khurasan covered the period between Ramadan 916 and Rajab 917/December 1510 and October 1511.

The Azerbaijan-based tiyzul-holders had altogether contributed 116 tümāns and 1000 dinars to the royal treasury over the course of four fiscal years. Their cash pay- 
Table 3. Taxes collected from tiyül-holders in Khurasan

\begin{tabular}{|c|c|c|c|c|c|c|c|}
\hline Tiyūl districts & $1507-1508$ & $1508-1509$ & $1509-1510$ & $1510-1511$ & $1511-1512$ & $1512-1513$ & TOTAL \\
\hline Bakharz $^{16}$ & & & & 13 & & & \\
\hline Balkh & & & & 7 & & & \\
\hline $\begin{array}{l}\text { Bastam \& } \\
\text { Damghan \& }\end{array}$ & & & & & & & \\
\hline Sabzivar & & & & 23 & & & \\
\hline Haratrud etc. & & & & 11.4 & & & \\
\hline Herat & & & & 6 & & & \\
\hline Khvaf & & & & 7 & & & \\
\hline Marv & & & & 14 & & & \\
\hline Mashhad & & & & 13 & & & \\
\hline $\begin{array}{l}\text { Mazar \& } \\
\text { Shaflan }{ }^{17} \text { etc. }\end{array}$ & & & & 28 & & & \\
\hline Nisa \& Bavard & & & & 3 & & & \\
\hline Sarakhs & & & & 14 & & & \\
\hline Turshiz etc. & & & & 14 & & & \\
\hline TOTAL & & & & 153.4 & & & 153.4 \\
\hline
\end{tabular}

ments ran to $16 \%$ of Shah Ismā'îl's share of the income from the taxes imposed on tiyül-holders between 914 and 918/1508 and 1512 (see Table 4). Per person, the amounts collected from this group of tiy $\bar{u} l$-holders normally ranged from 5 to $10 t \bar{u}$ $m \bar{a} n \mathrm{~s}$ in each fiscal year, indicating the new regime's moderate taxation in the districts ringed around Tabriz, a political move that was aimed to uproot the seeds of dissent among the Qizilbāsh. What is more, the imposition of such lower amounts of tax seems to have been due to the fact that tiyül-holders in Azerbaijan used to invest more money on raising and organising local tābin forces, which constituted the most accessible troop units at the time of military emergencies. At this early stage in the Safavid history, all tiyūl-holders in Azerbaijan were required to devote whatever resources at their disposal to "territorial expansionism" or mamlakat-gīrī (AFT I, f. 137r), suggesting that they were seldom allowed to commute their military service into monetary payment. As the most accessible military force, the Azerbaijan-based täbin regiments constituted the backbone of the Safavid army and as such they were certainly paid more than their counterparts in other provinces. Given the new regime's firm hold on bureaucratic life in Azerbaijan, the collection of the taxes levied on local tiyūl-holders was remarkably systematic and on-schedule. It was under these circumstances that the cash payments extracted from tiyül-holders in seven remote nomadic and rural settlements to the north of the Aras River in Qarabagh, Qapanat, and Chukhur-i

\footnotetext{
${ }^{16}$ About 130 miles to the southeast of Mashhad.

${ }^{17}$ Modern Pashtun Zarghun, some 15 miles to the east of Heart.
} 
Table 4. Taxes collected from tiyūl-holders in Azerbaijan

\begin{tabular}{|c|c|c|c|c|c|c|c|}
\hline Tìyūl districts & $1507-1508$ & 1508-1509 & $1509-1510$ & $1510-1511$ & $1511-1512$ & $1512-1513$ & TOTAL \\
\hline Arut & & 0.5 & & & & & 0.5 \\
\hline Bargushat & & 8 & & & 9 & & 17 \\
\hline $\begin{array}{l}\text { Bayezid \& } \\
\text { Maku }\end{array}$ & & & & & 1.8 & & 1.8 \\
\hline $\begin{array}{l}\text { Chukhur-i } \\
\text { Sa'd }^{\prime}\end{array}$ & & & 7 & & & & 7 \\
\hline Dihkhvaraqan & & & 1.2 & & & & 1.2 \\
\hline Ganja & & 7.2 & & & 5 & & 12.2 \\
\hline Garmrud & & 1.2 & & & 1 & & 2.2 \\
\hline Khalkhal & & & & 2 & & & 2 \\
\hline Khuy & & 1.2 & & & & & 1.2 \\
\hline Maragha & & 2 & & & 4 & & 6 \\
\hline $\begin{array}{l}\text { Miyanduab \& } \\
\text { Ushni }\end{array}$ & & & & 1.5 & & & 1.5 \\
\hline Mughanat & & & 8 & & 13 & & 21 \\
\hline Qarabagh & & 5 & & & & & 5 \\
\hline Salmas & & & 1.2 & & & & 1.2 \\
\hline Sarab & & 2 & 1 & 0.5 & 1.5 & & 5 \\
\hline Tarumayn & & & & 2 & & & 2 \\
\hline Turkmens & & & & 0.8 & & & 0.8 \\
\hline Ungud & & & 1.3 & & & & 1.3 \\
\hline Usku & & & & 1 & & & 1 \\
\hline Urmia & & & 4 & 13 & & & 17 \\
\hline $\begin{array}{l}\text { Varanda \& } \\
\text { Dizaq }\end{array}$ & & 5 & & 4.2 & & & 9.2 \\
\hline TOTAL & & 32.1 & 23.7 & 25 & 35.3 & & 116.1 \\
\hline
\end{tabular}

Sa'd came to be $45 \%$ (50 tümāns and 7000 dinars) of the shah's share of the income from direct taxation on tiyül-holders. Five of these seven tiyūl districts were dominantly Armenian-populated, which allowed the Qizilbāsh to impose higher taxes under religious pretexts in order to pay more cash to central treasury in Tabriz.

Diyarbakir, where more than twenty-five rural and urban districts had been assigned to tiy $\bar{u} l$-holders, made more than 125 tümāns of the shah's profits from direct taxation on tiyūl land assignments between 914 and 918/1508 and 1512 (see Table 5). As was the case with tiy $\bar{u} l$ land assignments in the Armenian-populated salient of Azerbaijan, the biggest amounts collected from the Diyarbakir-based tiy $\bar{u} l$-holders came from those who had been put in charge of the Christian-populated rural and urban settlements. For instance, the most productive tiy $\bar{u} l$-holders in eastern Anatolia 
Table 5. Taxes collected from tiyūl-holders in Diyarbakir

\begin{tabular}{|c|c|c|c|c|c|c|c|}
\hline Tiȳūl districts & $1507-1508$ & $1508-1509$ & $1509-1510$ & $1510-1511$ & $1511-1512$ & $1512-1513$ & TOTAL \\
\hline $\begin{array}{l}\text { Ahlat \& } \\
\text { Adelcevaz }\end{array}$ & & & & & 2.7 & & 2.7 \\
\hline $\begin{array}{l}\text { Amid \& } \\
\text { Mardin }\end{array}$ & & & & & 7 & & 7 \\
\hline Arabgir & & & & 7.7 & 2 & & 9.7 \\
\hline Atak & & & 1 & & & & 1 \\
\hline Bayburt & & & & 4 & & & 4 \\
\hline Çermik & & 1 & & & & & 1 \\
\hline Çemişgezek & & & 8 & & 14 & & 22 \\
\hline Çüngüş & & 0.6 & 0.9 & & & & 1.5 \\
\hline Ebu Tahir & & & & & & & 1.5 \\
\hline Eleşkirt & & & 1.5 & & 1 & & 1 \\
\hline Ergani & & & & & 5 & & 5 \\
\hline $\begin{array}{l}\text { Erzincan \& } \\
\text { Kemah }\end{array}$ & & & & & 15 & & 15 \\
\hline $\begin{array}{l}\text { Haçuk \& } \\
\text { Çapakçur }\end{array}$ & & & & & 2.5 & & 2.5 \\
\hline Harput & & 5 & 9 & 13 & & & 27 \\
\hline Hisnkeyf & & & & 4.2 & & & 4.2 \\
\hline Hazo & & & & 1.5 & & & 1.5 \\
\hline Hizan & & & & & 5 & & 5 \\
\hline Kulb & & & & & 5.2 & & 5.2 \\
\hline Palu & & & & & 1 & & 1 \\
\hline Ruha & & & 1.8 & 2 & & & 3.8 \\
\hline Savur & & 2.5 & & & & & 2.5 \\
\hline Siirt & & & 0.8 & & & & 0.8 \\
\hline Telguran & & & & 1 & & & 1 \\
\hline TOTAL & & 9.1 & 23 & 33.4 & 60.4 & & 125.9 \\
\hline
\end{tabular}

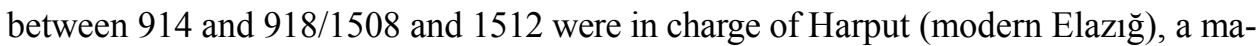
jor city to the west of Amid (or Kara-Hamid; present-day Diyarbakir) with a considerable Christian (Armenian, Nestorian, and Greek) population. ${ }^{18}$ Over the course of four fiscal years (914-918/1508-1512), the Safavid tiyül-holders in Harput made more than $20 \%$ (27 tümāns) of the taxes collected by the royal treasury from tiyülholders in Diyrbakir.

${ }^{18}$ Early in the 16th century, the Christian population of Harput was about 25,000, while the Muslim residents of the district amounted to about 14,500; see Ünal (1989, p. 73). 
The amounts deposited with the royal treasury by tiyūl-holders in Fars, Kirman, the Kalhur District, Khurramabad (Luristan), and Arabian Iraq (Baghdad) added up to 211 tümāns and 6000 dinars or about one third (29\%) of the shah's share of the income from tiy $\bar{u} l$ land assignments over the course of 914-918/1508-1512.

\section{Distributional Significance of Tiyūl Prebends}

On the eve of Shah Ismā'‘̂l's rise to power in the summer of 907/1501, the Aqquyunlu Sultanate consisted of two independent administrative zones. According to the peace agreement of Sa'in-Qal'a, which had been signed in 906/1500 between the Aqquyunlu claimants to the throne, prince Alvand (d. 911/1504) and prince Murad (d. 920/1514), the eastern zone, including the provinces of Persian Iraq, Arabian Iraq, Fars, and Kirman, belonged to Murad and his descendants, while the western zone, which consisted of the provinces of Diyarbakir, Van, and Azerbaijan, was supposed to be ruled by Alvand and his successors (AFT I, f. 55r). The advent of the Qizilbāsh and their territorial conquests between 907 and 914/1501 and 1508 (Sarwar 1939, pp. 32-54; Savory 1965, pp. 71-94) ended this administrative divide and coalesced all these provinces into a single administrative unit controlled by Shah Ismā‘̄il and the Safavid tiy $\bar{u} l$-holders.

Under Shah Ismā'îl, almost all major urban centres in Iran and eastern Anatolia were administered as tiyül. Twenty-eight out of more than eighty districts enfeoffed as $t i y \bar{u} l$ between 914 and 918/1508 and 1512 are localised to the province of Diyarbakir. Azerbaijan and Persian Iraq had twenty-five and sixteen tiyūl land assignments respectively. In Khurasan, more than fifteen rural and urban settlements were run as tiyūl in 916/1510-1511. The concentration of more than half of early Safavid tiy $\bar{u} l$ districts in the frontier provinces of Diyarbakir and Khurasan highlights the importance of the practice as a mechanism of territorial expansion and administrative control under Shah Ismā'īl. During this period, tiyūl land assignments in such geographically central provinces as Fars, Persian Iraq, and Kirman were no more a than a cluster of borderland military outposts that for the most part abutted the territories of local dynasties in Luristan (and Qara-Ulus), Kurdistan (the Kalhur and 'Ali-Shakar Districts), Laristan, Hormuz, Khuzistan (or Huvayzah; also Arabistan), and the Caspian provinces of Rasht, Lahijan, Rustamdar, and Mazandaran. ${ }^{19}$

\section{IV.a. Eastern Anatolia}

Persian narrative sources are reticent on administrative status of the province of Diyarbakir under Shah Ismā' 1 l; instead, they have tended to play up the military feats of the Qizilbāsh against the Aqquyunlu, Kurdish, and Zu'l-Qadr nucleuses of resis-

\footnotetext{
${ }^{19}$ For more on these local dynasties, see Nuvīdī Shīrāzī (1369 Sh./1989, pp. 131-145).
} 
tance in Mardin, Cizre, and Harput. ${ }^{20}$ Even modern scholarship on early Safavid Diyarbakir is garbled. In a recent article on Shah Țahmāsb's (930-984/1524-1576) Kurdish policy, Akihiko Yamaguchi (2012, p. 108) misinterprets Sharaf Khan Bidlīsì's detailed narrative on the Safavid regime's crackdown on Kurdish city-states of eastern Anatolia to hammer out a revisionist account on what he dubs the "appeasing" and "conciliatory tone" of Shah Ismā'îl's relations with the Kurdish powerbrokers and ruling families of the region. As we shall see in this present article, the enfeoffment of the Kurdish city-states of the province of Diyarbakir as tiy $\bar{u} l$ under Shah Ismā $\overline{1} 1$ had been carried out with the objective of sweeping away the last vestiges of the Aqquyunlu system of local alliances and proxy control.

Around the time of the Qizilbāsh conquest of Amid, the capital city of the province of Diyarbakir, it was a fortress town of about 13,000 (about 2400 households) inhabitants clustered by a dozen rural and nomadic settlements (İlhan 1977, p. 22). ${ }^{21}$ Economic recession and demographic decline marked this period of interregnum $(S N$, f. $80 \mathrm{v})$. The fact that under Shah Ismā'îl Amid had only once been assigned as tiy $\bar{u} l$, in the fiscal Year of the Monkey or 917-918/1511-1513, is a testimony of the new regime's efforts to refrain from overtaxing fiscal resources in the region. Under Shah Ismā'îl, the tiyūl districts operating in the administrative orbit of Amid were as follows: Kulb (modern Kulp), Kemah, Ruha (modern Urfa), Arabgir, Ergani, Atak (also Hatakh; modern Lice) (Tîgrîs 2008, p. 14), Palu, Hizan (some 30 miles to the southeast of Bitlis), Hazo (or Hizo; present-day Küyübaş1, few miles to the south of Batman) (Bidlīsī 1860-1862, Vol. 1, p. 191), Çermik, Çapakçur (also Çevlîk; modern Bingöl), Çüngüş, Haçük (or Haçık; modern Elbeğendi, some 15 miles to the northwest of Viranşehir) (Barkan 1953-1954, p. 307; Göyünç 1969a, p. 203), Savur (some 30 miles to the northeast of Mardin) (Göyünç 1969b, pp. 39-40), Telguran (or Tell-i Kuran; present-day Yollarbaşı, some 10 miles to the northwest of Viranşehir) (Göyünç 1969b, p. 41), Hısnkeyf (modern Hasankeyf), and Siirt. ${ }^{22}$ Early in the 16th century, except for Harput, Amid, Ergani, and Ruha, the rest of the above-mentioned tiyūl districts made up the "Cemaat-1 Kurdân" or Kurdish communities of Diyarbakir (Barkan 1953-1954, pp. 306-307; cf. Tezcan 2000; Posch 2013, pp. 78-81).

To the west of Amid, Harput was the second most important urban centre in the province of Diyarbakir under Shah Ismā'īl. The Qizilbāsh conquered the city in the summer of 913/1507 after forcing out a Zu'l-Qadr troop unit, and governed the city

\footnotetext{
${ }^{20}$ The most detailed accounts on the Safavid conquest of eastern Anatolia under Shah Ismā‘ ${ }^{\wedge} 1$ can be found in Ghaffārī Qazvīnī (1343 Sh./1964, pp. 270-271); and Husaynī Qumī (1383 Sh./2004, pp. 89-93).

${ }^{21}$ In the spring of 914/1508, when the Qizilbāsh took over Amid, Muhammad Khan Ustājlū (d. 920/1514), a scion of a family of local landed notables, was made governor of the city and the province of Diyarbakir; see Ghaffārī Qazvīnī (1343 Sh./1964, p. 270); Rūmlū (1383 Sh./2004, p. 904). In 948/1541, local population in Amid amounted to more than 3400 households (Tenreiro 1923, p. 57; Barkan 1957, p. 27).

${ }^{22}$ For more on administrative divisions of the province of Diyarbakir in the first quarter of the 16th century, see D. 9772 (Topkapı Palace Museum Archives, Istanbul), ff. 4r-5r, reproduced in Göyünç (1969a, pp. 26-28); cf. Van Bruinessen (1988, p. 19); Baykara (1998, p. 102); Ünal (1999b, pp. 172-173).
} 
for about a decade until the spring of 922/1516 (Hoca Sa'dettin 1979, Vol. 4, pp. 262-263; Ünal 1989, pp. 23-27; Amīnī Haravī 1383 Sh./2004, pp. 280-281; SN, f. 114r). That immediately after Shah Ismā‘̄il's capture of Harput a group of böy nökar or the Aqquyunlu special forces ${ }^{23}$ had been allowed to take care of the city's fiscal administration as tiyunl-holders bespeaks the political clout the Aqquyunlu still wielded in the region. After 861/1465, the Aqquyunlu had moved their harem to Harput so that Uzun Hasan's fourth wife the Komnene princess Theodora of Trabzon could take up residence in the city together with her Greek retainers (Angiolello 1980, p. 369; Barbaro 1980, p. 550; Woods 1999, p. 95; Shukurov 2001, pp. 319-321). In the closing years of the 15th century, the Aqquyunlu prince Rustam, a grandson of Theodora of Trabzon, made Harput his capital, and minted the new regime's coins in the city (Ardiçoğlu 1964, p. 73; Woods 1999, pp. 155-158).

Put on map (see Map 1), tiy ūl districts in eastern Anatolia formed an arrowshaped line-up of fortress towns and military outposts stretched westward from Van to Amid to Harput. Bayburt, Erzincan, Kemah, Çemişgezek, and Arabgir sit on the northern side of this arrow, while the tiy $\bar{u} l$-holders stationed in Ruha, Telguran, and Mardin supervised the administrative affairs of the districts concentrated along the southern side. Between 914 and 916/1508 and 1510, the Safavid tiyūl districts in Diyarbakir clustered around the region to the south of Amid. But beginning in 917/15111512 more tiy $\bar{u} l$-holders were posted to the northern and northwestern confines of the province. This shift in posting pattern reflected the changing military priorities of the Safavid regime. While the appointment of tiyūl-holders in Diyarbakir between 914 and 916/1508 and 1510 was aimed to expedite dynastic transition in the Kurdish citystates of eastern Anatolia, after 917/1511-1512, the outbreak of succession wars in the Ottoman Empire and the subsequent enthronement of Selim I in Safar 918/AprilMay 1512 (Uluçay 1954b, pp. 127-131; Uluçay 1955, pp. 191-198) forced the Safavids to ease up pressure on Kurdish fortress towns of southern and central Diyarbakir and shift more tiyūl-holders to the north, northwest, and west of Amid and Harput.

Almost all tiyūl-holders posted to northern and western Diyarbakir in 917/15111512 were high-ranking military commanders, including one Tekkelū, one Varsāq/Rūmlū, two Ustājlū, and two Zu'l-Qadr emirs. But less than three years into their appointment as tiy $\bar{u} l$-holder, when the Ottoman armies invaded eastern Anatolia, none of them was able to resist their progress. Why? Part of their failure arose from the fact that, aside from Harput, Çemişgezek, and Erzincan, the rest of the tiyūl districts in western Diyarbakir, including Çermik, Çüngüş, ${ }^{24}$ and Ebu Tahir (modern Sivir-

\footnotetext{
${ }^{23}$ Under the Aqquyunlu, the royal guards were called böy nökar (Tịhrānī 1962-1964, pp. $81,175,200,272,279,385,422,555$; cf. Doerfer 1963-1967, Vol. 2, pp. 358-359; cf. Fleischer 2011 , p. 550); but in the latter part of the 16th century, the word böy nökar got a pejorative meaning and was applied to bandits and urban riffraff (Nuvīdī Shīrāzī 1369 Sh./1990, p. 99).

${ }^{24}$ According to the administrative and fiscal regulations prepared for Çüngüş under Uzun Hasan and updated immediately after the Ottoman annexation (Barkan 1943, pp. 152-153), the district consisted of only one fortress ( $h i s \hat{a} r)$ around which clustered six rural settlements inhabited by the Armenian and Nestorian Christians.
} 


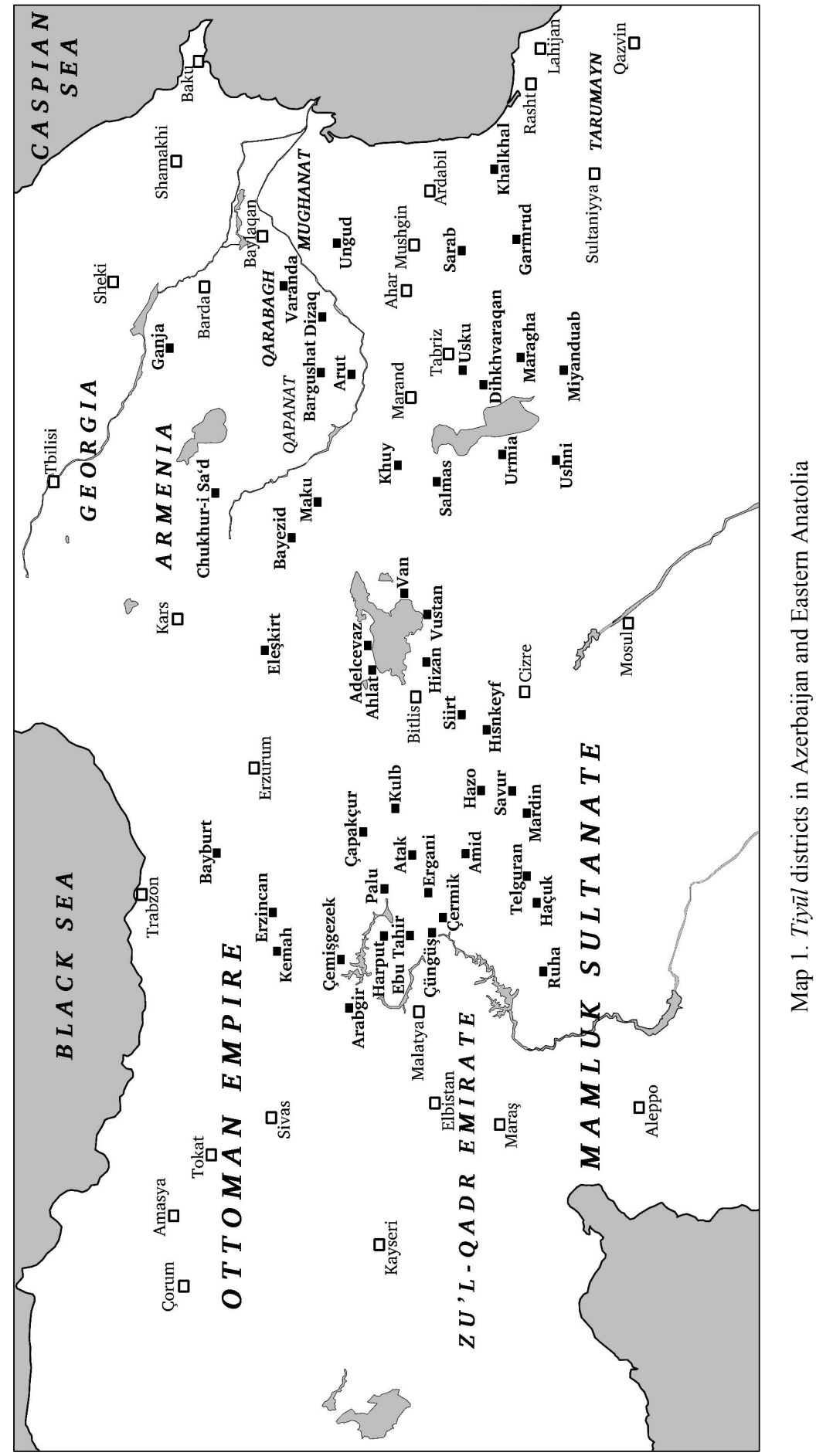


ce) ${ }^{25}$ were of little or no strategic significance. Far off the route that led from Harput to Amid via Ergani, these three tiyül land assignments formed an isolated archipelago of upland military outposts. Direct taxation on tiyūl-holders in charge of all three districts between 914 and 918/1508 and 1512 had generated less than 5 tümāns. Cash payments collected from Çermik and Ebu Tahir had been received only once, implying the new regime's lack of effective control over both military outposts.

Arabgir, Çemişgezek, Kemah, Erzincan, and Bayburt were of greater importance both strategically and administratively. During 916-918/1510-1512, when it was still a tiyūl district, Arabgir spearheaded the Safavid defense line in western Diyarbakir, bordering the Mamluk and Ottoman garrisons in Malatya and Sivas. ${ }^{26}$ There is evidence to suggest that a combination of fiscal mismanagement and political wrong moves undercut the Qizilbāsh influence across the northern and northwestern confines of Diyarbakir. The Safavid tiy $\bar{u} l$-holders in Arabgir seems to have been subject to excessive taxation, generating 7 tümāns and 7000 dinars for the shah in a single fiscal year, i.e. $916 / 1510-1511$, an amount that equaled approximately $15 \%$ of the taxes levied on the rest of the tiyull-holders in Diyarbakir in the same fiscal year. The preamble to the Ottoman fiscal regulations for Arabgir in 924/1517-1518 makes it clear that the local population had been overtaxed under the Safavids (Barkan 1943, p. 171). In a similar manner, a local Armenian historian points to the "atrocities and destruction caused by the Safavids that led to the depopulation" of Kemah following the advent of Shah Ismā'îl (Zulalian 1971, p. 62). Be that as it may, Arabgir was home to an influential nucleus of military supporters of the Safavid regime in western Diyarbakir (Anonymous 1361 Sh./1982, p. 25; Posch 2013, p. 189). Perhaps the two less-known tiyūl-holders whose names appear in the list of the shah's share of the income from tiy $\bar{u} l$ as military governors of Arabgir in 916/1510-1511 represented the local stalwarts of the Safavid cause in the region. One of them, a certain Kurd-'Ali Beg a.k.a. Kurd Beg, survived the Ottoman invasion of eastern Anatolia and shortly thereafter moved to Azerbaijan. ${ }^{27}$

Early in the 16th century, Kemah had retained the military and strategic importance it enjoyed during Tamerlane's invasion of Anatolia in 804/1401. ${ }^{28}$ Late in the 15th century the fortress town was a major administrative hub in northwestern Diyarbakir and a branch of the Aqquyunlu central treasury is reported to have operated from Kemah (Barkan 1943, pp. 184-185; Celâl-Zade Mustafa 1990, p. 390; KhunjīIșfahānī 1992, p. 153). In the fiscal Year of Monkey or 916/1510-1511, Kemah was

\footnotetext{
${ }^{25}$ Early in the 16th century, Ebu Tahir was a rural backwater to the north of Çermik; for more on its administrative status at that time, see Barkan (1943, pp. 169-170).

${ }^{26}$ For the appointment of a Mamluk $n \bar{a} ' i b$ in Malatya in 918/1512-1513, see E. 8757 (Topkapı Palace Museum Archives, Istanbul), reproduced in Bacqué-Grammont (1987, p. 41; cf. Bidlīsī $1860-1862$, Vol. 1, pp. 166-167).

${ }^{27}$ E. 9647, Topkap1 Palace Archives, Istanbul, reproduced in Bacqué-Grammont-Adle (1986, p. 100); cf. Simões (1898, p. 248).

${ }^{28}$ Located on the foothills of the Munzur mountain track in Dersim, early 15 th-century Kemah was the seat of the Mutahharten's anti-Ottoman emirate and one of the key bones of contention between Iranian and Central Asian army of Tamerlane and Bayezid I (791-805/1389-1403); see Yazdī (1387 Sh./2008, pp. 1123, 1125-1126); cf. Miroğlu (1990, p. 6).
} 
administered as tiyūl, where the Safavid tiy $\bar{u} l$-holder, who governed the fortress from Erzincan, paid a total of 15 tummanns to central treasury or $20 \%$ of the taxes extracted from the Diyarbakir-based tiy $\bar{u} l$-holders in the same fiscal year. In the autumn of 920/1514, the tiy $\bar{u}$-holder in charge of Kemah and Erzincan mounted a series of desperate guerrilla attacks against the Ottoman armies on their way back from Tabriz. But communication lines with Tabriz and Amid had already been cut off and it took only few months for the Ottomans to capture Kemah and Erzincan, which occurred in Rabi` II 922/May 1516, paving the way for Selim I to set the stage for a major military campaign against the $\mathrm{Zu}$ 'l-Qadr emirate to the south (Feridun Bey 12651274 AH/1848-1858, Vol. 1, pp. 407-411; SN, ff. 95v, 102v-104r; Miroğlu 1989, p. 97; Celâl-Zade Mustafa 1990, pp. 391-392; Gelibolulu Mustafa Ali 2009, f. 238r).

Assigned as tiyūl to a Chapnī military chief in 916/1510-1511, Bayburt was the closest Safavid military base to Trabzon, which between 892/1487 and 916/1510 had been appanged to the Ottoman prince Selim (Emecen 2011, p. 33; Uluçay 1954a, p. 74). To the east of Trabzon, Ovacik was the westernmost military outpost of the Aqquyunlu to the north of Bayburt (E. 3160, reproduced as document XXIX in Fekete 1977, p. 230). Tercan, Kovans, and Kelkit were three major rural settlements in the vicinity of Bayburt, of them Tercan is reported to have been a centre of pro-Safavid activities in the region in the early years of the 16th century. On the eve of the Ottoman invasion of eastern Anatolia and Azerbaijan, a Safavid military chief had been stationed in Tercan, leading local supporters of Shah Ismā'îl against the intruders (SN, f. 77v; Celâl-Zade Mustafa 1990, p. 372). The appointment of a Chapnī emir as tiy $\bar{u} l$-holder in Bayburt was not accidental; it took place at a time when a collateral branch of the Chapni tribe led the Ottoman military base in Trabzon under the command of prince Selim. ${ }^{29}$ The likely prospect of the Qizilbāsh conquest of Trabzon in the wake of Selim I's departure to Istanbul must have driven Shah Ismā‘îl to capitalise on inter-tribal divides between the Chapnīs of both cities. About half a century prior to this, Shaykh Junayd (d. 860/1456) and his disciples had laid a very successful siege to Trabzon and captured the city briefly before the outbreak of a plague epidemic forced them to leave the region for Georgia and Dagestan on a campaign of looting against non-Muslim denizens of both provinces (Shukurov 1993). But so far as Shah Ismā'̄il's in-the-making campaign against the Ottoman garrison in Trabzon is concerned, all these proved to be a political miscalculation. In less than three years after its incorporation into tiy $\bar{u} l$ system, Bayburt was witness to the revolt of a Döğer military chief named Rustam Beg, during which the city was purged of high-ranking pro-Safavid elements and Rustam Beg entered an alliance with the Ottomans (Gökbilgin 1951, p. 40; cf. Celâl-Zade 1990, p. 384; Gelibolulu Mustafa 'Ali 2009, f. 236v). There is evidence to suggest that the Qizilbāsh failure in Bayburt had also to do with their fiscal mismanagement: the findings of an Ottoman cadastral survey in 946947/1540 indicates that the Safavid annexation of Bayburt in 913/1508 and the military

\footnotetext{
${ }^{29}$ On the Chapnī emirs at the court of prince Selim, see Başbakanlık Arşivi Maliyeden Müdevver Defterler, no. 17893, pp. 142, 144, 146, 147, 242, 291, cited by Emecen (2011, p. 41). On the Chapnī nomads of Trabzon in the first quarter of the 16th century, see Sümer (1992, p. 61); Posch (2013, p. 191).
} 
conflicts that ensued following the advent of Sultan Suleiman (926-974/1520-1566) had resulted in depopulation of more than 120 rural settlement in the region (Miroğlu 1975, pp. 25, 30, 32).

The way in which the Safavids dealt with the Kurdish city-state of Çemişgezek and its ruler Hājē Rustam Beg Malkishī (d. 920/1514) throws light on the policy of using tiyūl as a mechanism of dynastic changeover in eastern Anatolia. At the time of the Qizilbāsh conquest of Diyarbakir, the township of Çemişgezek had a taxpayer population of up to 350 households, of which about two thirds were non-Muslim (Ünal 1999a, p. 60). Hạj̄ī Rustam was one of those few Kurdish rulers in Diyarbakir who, in 913/1508, threw their support behind Shah Ismā'îl. Prior to his collaboration with the Safavids, the Ottomans had tried to win Hājī Rustam's allegiance, urging him to stop Turkmen nomads of central Anatolia to make their way into Diyarbakir and Azerbaijan (Feridun Bey 1265-1274 AH/1848-1858, Vol. 1, pp. 353-354). Hājī Rustam failed to comply with Bayezid II's (886-916/1481-1512) order and soon allied himself with the Qizilbāsh. At the beginning, Shah Ismā'īl allowed Hāj̄̄ Rustam remain in his hereditary post as governor of Çemişgezek, but in 917/1511-1512, and not in 913/1507-1508 as Bidlīsī (1860-1862, Vol. 1, pp. 164-167) claims in his account on Hājī Rustam's career, the Qizilbāsh sent him and his relatives to exile in Azerbaijan and made a Tekkelu tiyül-holder governor of Çemişgezek. In the summer of 920/1514, Selim I captured Hājī Rustam and his clan in Marand, where they lived under house arrest, and put them to sword on account of their betrayal to the Ottoman cause under Bayezid II (Tekindağ 1968, p. 75; Hoca Sa'dettin 1979, Vol. 4, pp. 219 220; Gelibolulu Mustafa 'Ali 2009, f. 236r). The Safavid tiyūl-holder in charge of local administration in Çemişgezek is reported to have dealt with local population heavy-handedly (Bidlīsī 1860-1862, Vol. 1, p. 165), pushing them further toward collaborating with the Ottomans shortly after Selim I's rise to power.

Similarly, local powerbrokers in Hizan and Hazo were pro-Safavid at the outset of Shah Ismā'îl's conquest of Diyarbakir. Early in the 16th century, Hazo was a major rural settlement to the south of Sason (or Sasan) inhabited by 500 to 600 households of Nestorian Christians (Tenreiro 1923, p. 54). They paid their taxes and tributes to the Kurdish governor of Sasaon, 'Alī Beg Sāsān̄̄, who traced his descent to the Sasanid kings of Iran and was reportedly a stalwart of the Qizilbāsh cause in eastern Anatolia. 'Al̄̄ Beg Sāsān̄̄ had given away his daughter in marriage to Sharaf Beg b. Shah Muhammad Rūjakī, the governor of Bitlis, who, in 913/1508, was jailed by the Safavid governor of Amid Muhammad Khan Ustājlu. But as a result of 'Alī Beg's rapprochement with the Qizilbāsh Shah Ismā'īl recognised Sharaf Beg as an ally (Bidlīsi 1860-1862, Vol. 1, p. 411) and kept him for about two years (913916/1507-1510) in his post as governor of the strategic city of Bitlis, which in the first part of the 16th century was known as "the gate of Azerbaijan". ${ }^{30}$ Like Hājī Rus-

${ }^{30}$ See documents A.DVN.950.171 and A.DVN.937.117 (both dated late autumn 940/1533) in Bacqué-Grammont (1991, pp. 151, 162). Shortly after 913/1507-1508, Sharaf Beg was put in jail in Tabriz and later on accompanied Shah Ismā'īl as a prisoner in the course of the Qizilbāsh invasion of Khurasan, during which he somehow managed to flee to eastern Anatolia (Bidlīsì $1860-1862$, Vol. 1, p. 411). 
tam of Cemişgezek, on the eve of the Ottoman offensive in 920/1514 'Alī Beg was summoned to Tabriz, where he spent his last years as a "confidant" of Shah Ismā'îl. But after his death in Tabriz, 'Alī Beg's son Khiżr Beg sided with the Ottomans and was consequently restored as the governor of Sason and Hazo under Selim I (Bidlīsì 1860-1862, Vol. 1, p. 193). In Hizan, where Dāvūd Beg b. Amīr Malik (fl. 920s/15241535), a native of Hinis, acted as local ruler under Shah Ismā' ${ }^{\prime} 1$, the Safavids first allowed the local authorities to take care of fiscal and administrative affairs of the town, but in less than two years, Dāvūd Beg and his allies in Hizan were arrested and shortly before Selim I's invasion of Azerbaijan a Safavid military chief was made governor of Hizan (Bidlīīi 1860-1862, Vol. 1, p. 412).

Likewise, in Palu and Atak, the Safavid practice of tiyūl paved the way for the elimination of local powerbrokers and ruling families. Early in the 16th century, Atak, a fortress town standing astride the route leading from Amid to Bitlis, was the seat of local rulers affiliated with a collateral branch of the Mardin-based Zarqī (or Azraqī; also Zīrakī) clan, who since 881/1477 had vowed allegiance to the Aqquyunlu (Khunjī Ișfahānī 1992, p. 126). At that time, Atak was the administrative centre of two rural districts named Bilan and Serde and sixty villages. Like the rest of eastern Anatolia, Armenian and Nestorian Christians constituted the majority of local population, and the findings of an early 16th-century cadastral survey by the Ottomans indicates that in the first part of the century out of a total of 12,500 souls more than 10,000 were nonMuslim (Bizbirlik 1999, pp. 111-113). The Safavids conquered Atak in 913/15071508 and forced out the Zarqī clan. Shortly thereafter, a group of Qājār Turkmens moved in and took charge of the Safavid garrison in Atak. The taxes collected from the new regime's tiyūl-holders in Atak were spent on the Qizilbāsh forces stationed in Azerbaijan and Persian Iraq. A similar pattern of political transition shaped the Qizilbāsh capture of Palu, a fortress town controlled by the Bulduqānī and Pāzūkī clans of the Mardāsī (or Mardīsī) tribal confederation of Kurdistan and Diyarbakir (Aydın 2011, pp. 308-314; cf. Woods 1999, pp. 186-187, 194; Posch 2013, pp. 85-87). In 917/1511-1512, the Safavids appointed a tiyül-holder as governor of Palu amid the outbreak of a succession crisis at the local court following the death of Husayn Beg Bulduqānī during a raid against the pro-Aqquyunlu forces in Ergani. It was only after the Ottoman conquest of eastern Anatolia in 922/1516 that the Bulduqāni and Pāzūkī rulers of Palu, led by Jamshīd Beg b. Husayn Beg, were restored (Bidlīsī 1860-1862, Vol. 1, pp. 184-185; Ünal 1999c, pp. 213-214).

Under Shah Ismā'īl, Hisnkeyf, a small fortress town on the southern bank of the Tigris River in Diyarbakir, went through a similar process of degradation from an independent city-state to a tiyūl district. The Ayyubid rulers of Kurdistan ruled from Hisnkeyf. Early in the 890s/late 1480s, the local ruler Malik Khalīl b. Sulaymān Ayyūbī (d. after 920/1514) extended his rule to Siirt, a fortress town to the south of Bitlis (Barbaro 1989, pp. 529-530). Shortly thereafter, he captured the Safavid Shaykh Haydar's female descendants on their way from Diyarbakir to the Hejaz, fleeing the Aqquyunlu persecution in Azerbaijan and eastern Anatolia. Malik Khalīl then married his eldest daughter, but during the years leading up to Shah Ismā‘̄il's seizure of political power he is reported to have sided with anti-Safavid forces in the 
region ([Romano] 1980, p. 432). ${ }^{31}$ After the summer 907/1501, however, Malik Khalīl visited Tabriz to vow loyalty to his newly enthroned brother-in-law Shah Ismā'̄il, but upon arrival in the city he was jailed and during a decade of hiatus that ensued, both Hısnkeyf and Siirt were assigned as tiyūl to the Qizilbāsh (Bidlīsī 1860-1862, Vol. 1, pp. 155-156; Seçkin 2006, pp. 88-89; Gelibolulu Mustafa 'Ali 2009, f. 240v). In 916/1510-1511, Muhammad Khan Ustājlū appointed his brother Qarā Khan as tiy $\bar{u} l$-holder in Hisnkeyf, while a year before this, Siirt had been assigned as tiyyul to a Qājār military chief.

The integration of Kulb and Çermik into the tiyūl system of land tenure after 913/1507-1508 brought about the downfall of local ruling families. Early Safavid Kulb had seen the decline of a dynasty of Kurdish rulers who ruled from Batman and traced their descent to the Umayyad caliphs. During the civil wars that broke out in both cities early in the 910s/1505-1515, the Safavid governor of Amid, who had married a female member of the Batman-based branch of the ruling family, intervened and eventually managed to bring both urban centres under the Safavid rule (Bidlīsi 1860-1862, Vol. 1, pp. 264-265). In 914/1508-1509, Çermik became tiyül and a Qizilbāsh military chief replaced the Kurdish ruling family at the helm of local administration (Bidlīsī 1860-1862, Vol. 1, p. 190).

\section{IV.b. Iran}

Administratively, the early Safavid tiyyul districts in the province of Azerbaijan clustered around Ganja and Chukhur-i Sa'd to the north and Tabriz to the south (see Map 1). To the northwest, Eleşkirt, a military outpost and nomadic settlement (ovâ), which in 916/1511-1512 was administered as tiyūl land assignment, separated Azerbaijan from Diyarbakir (Matrakçi 1976, p. 82; Kırzıŏglu 1993, p. 107; Posch 2013, p. 47). To the southwest, Bitlis was under the jurisdiction of the Safavid provincial administration in Azerbaijan. Besides Eleşkirt and the neighbouring fortresses of Maku and Bayezid (or Mağazird), the districts of Kulb, Van, Vustan (modern Gevaş), Ahlat, and Adelcevaz $^{32}$ were administered from Bitlis (K1lıç 1999, pp. 17-18) and as such all were part of the province of Azerbaijan. There is evidence to suggest that out of these last five tiyūl districts the Qizilbāsh had plundered Van and Vustan in 910/1504. According to the account given in a contemporary Armenian chronicle, under the Qizilbāsh, whom it described as "a bunch of bloodsuckers called redhead Sufis", both districts, which were predominantly inhabited by Armenian Christians, were on the verge of total ruin and depopulation (Zulalian 1971, p. 62). ${ }^{33}$

\footnotetext{
${ }^{31}$ On Romano and the authorship of his travelogue, see Aubin (1995, pp. 255-259).

${ }^{32}$ In 920/1514, Ahlat and Adelcevaz had been depopulated to the effect that Shah Ismā'il declared both cities free tax zones; see E. 5831, in Fekete (1977, pp. 315-316).

${ }^{33}$ For much of the two decades to come Van and Vustan remained in the same conditions. Late in the 920s/early 1530s, the region was the scene of border clashes between the Qizilbāsh and emir of Bitlis, Sharaf Beg Rūzakī; see Ovanes of Erciyes (1971, pp. 126).
} 
In Qarabagh, the early Safavid tiyūl districts were Ganja, Varanda (modern Füzuli District in Nagorno-Karabakh), Dizaq (modern Jabrayil District in Nagorno-Karabakh), Mughanat, and Bargushat in Qapan. During 914 and 916/1508-1509 and 1510-1511, Varanda and Dizaq had been assigned as tiyūl to Pīrī Beg Qājār, the governor of Qarabagh. Pīrī Beg had been recruited to raise an army from among the nomads of Qarabagh (AFT I, ff. 112r, 115r). Another tiy ül district in Qapan was the village of Arut, ${ }^{34}$ which in $915 / 1509-1510$ had been assigned to a prominent Qizilbāsh military chief. For much of the 16th century, the nomads of Qarabagh, coalesced into the twenty-four (Igirmidört) and thirty-two (Otuz-İk1) tribal confederations, ${ }^{35}$ were among the key allies of the Safavids in the northern salient of Azerbaijan. The findings of a late 16th-century cadastral land survey conducted by the Ottomans show that the district of Dizaq had jurisdiction over several dozen rural settlements, mostly presided over by local Armenian potentates (699 Tapu Tahrir Defteri, pp. 98-99; Kırzıoğlu 1993, p. 373; AFT III, f. 206r). Early Safavid Varanda, some 35 miles to the northeast of Dizaq, was the administrative centre of more than 120 rural settlements (699 Tapu Tahrir Defteri, pp. 98-99; Kırzıoğlu 1993, p. 373) ${ }^{36}$ As was the case with non-Muslim (Armenian and Nestorian) communities of eastern Anatolia, excessive taxation on Armenian denizens of Qarabagh accounted for the relatively high amounts of cash payments collected from local tiy $\bar{u}$-holders.

To the south of the Aras River, tiyül-holders in charge of Usku, Dihkhvaraqan (modern Azar-Shahr), and Maragha paid less than 5 tümāns to central treasury over the course of five fiscal years. This amounted to less than $2 \%$ of the shah's share of the income from tiyūl districts in Azerbaijan. The lower rates of the cash payments made by the tiy $\bar{u} l$-holders stationed in the vicinity of Tabriz can be taken to imply that the central authorities were careful not to drive a wedge between the shah and the Azerbaijan-based military elites by bringing them under fiscal pressure. To the east of Tabriz, Ungud, ${ }^{37}$ Sarab, Garmrud (present-day Miyana), Khalkhal, and Tarumayn ${ }^{38}$ were administered as tiyül. All these tiyül districts had played a crucial role in Shah Ismā'îl's ascent to the throne in 907/1501.

Little is known about the administrative status of most of the tiy $\bar{u} l$ districts in Azerbaijan during the reign of Shah Ismā'îl. The sole exception is Khuy, the site of

\footnotetext{
${ }^{34}$ On the location of Arut, see document XI (dated Shawwal 915/January-February 1510) in Papazian (1956-1968, Vol. 1, p. 265).

35 On the Igirmidört, which were mainly of Kurdish origins, see Bidlīsī (1860-1862, Vol. 1, p. 323); AFT II, f. 145v; Petrushevskii (1949, pp. 135-136). On the Otuz-İk1 clans, see AFT III, ff. 155v, 166v, 169v, 196v, 295v, 311v, 541r; Kırzığlu (1979, p. 210).

${ }^{36}$ In 1005-1006/1597, the Ottoman and Tatar armies are reported to have massacred Armenians of Dizaq and Varanda; see Arak'el of Tabriz (2010, pp. 41, 486).

${ }^{37}$ Ungud is located some 65 miles to the north of Mushgin (modern Mushkin-Shahr); see $A F T I I I$, f. 48v; on geographical local of Ungud, see $I V G$, Vol. 1, pp. 58-60.

${ }^{38}$ Tarumayn (now Upper and Lower Tarum) stands astride the route leading from Abhar to Zanjan; see $I V G$, Vol. 16, pp. 14-17. In 921/1515, a population of five hundred inhabitants lived in Tarumayn and it was governed from Khalkhal; see Simões (1898, p. 236); cf. Smith (1970, p. 40); Aubin (1986, p. 43).
} 


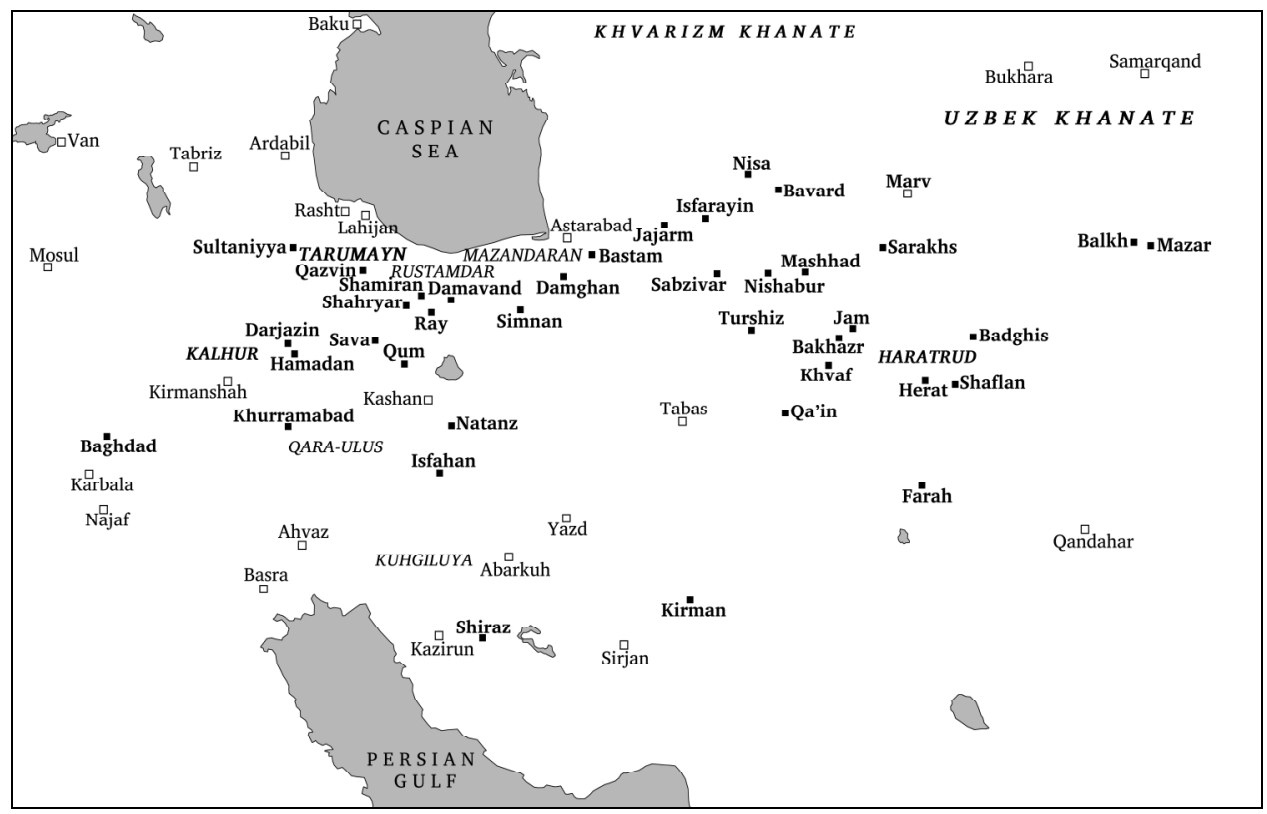

Map 2. Tiyūl districts in Iran

a Safavid royal palace (dawlatkhāna) early in the 16th century (Angiolello 1980, p. 399; [Romano] 1980, p. 442; Riyāhī 1372 Sh./1993, pp. 88-90). According to an early Safavid chronicle, the city had been assigned as tiyyul to an Ustājlū military chief in 913/1507-1508 (Ghaffārī Qazvīnī 1343 Sh./1964, p. 270), but there is evidence to suggest that in the same year Khuy had been assigned as tiyül to the shah's nephew Durmush Khan Shāmlū (d. 931/1525). The administrative status of Sarab also needs some clarifications. Between 914 and 918/1508 and 1512 Sarab had been assigned as tiyūl to a certain Khush-Andām Beg, who was likely to have been a boon companion of the shah. He was the only tiyül-holder in the country that had made cash payments to central treasury during four consecutive fiscal years. As tiyül-holder in Sarab, Khush-Andām Beg was in charge of the Turkmen nomads of the region between Sarab and Ahar, which in the later Safavid narrative sources were known as the Khalajs of Sarab (AFT III, f. 427r).

In Persian Iraq, tiyūl land assignments were mainly concentrated along the border with the Caspian emirates of Gilan-i Biyah Pas (Rasht), Gilan-i Biyah Pas (Lahijan), Rustamdar (Nur and Kujur), and Mazandaran (see Map 2). In 914 and 916/15081509 and 1510-1511, two Safavid tiyūl-holders affiliated with the Varsāq uymāq of the Rūmlū clan held the districts of Shamiran, Shahryar, Ray, and Damavand to the south of the war-torn province of Rustamdar. Their appointment coincided with the outbreak of succession wars between the claimants to the throne in Nur and Kujur (Ghaffārī Qazvīnī 1343 Sh./1964, p. 187; Nuvīdī Shīrāzī 1369 Sh./1990, p. 138; AFT I, f. 70r), which makes it likely to assume that these tiyül-holders had been recruited to make preparations for the conquest of Rustamdar in near future. Contemporary narra- 
tive sources highlight the demographic decline in major urban centres in Persian Iraq at the close of the 15th century. Iosafat Barbaro (1980, p. 547; Aubin 1986, p. 39), who had visited the area in the closing quarter of the century, clarified that the major cities in Persian Iraq had been "ruined for the most part". For instance, as an early Safavid tiyül district, Isfahan had suffered the massacre of its Sunni population in the hands of the Qizilbāsh (Tenreiro 1923, pp. 20-21).

The distribution of tiyūl districts in Khurasan, from Damghan to Mazar (or Mazar-i Sharif), was aimed to creat a multi-layered line-up of military outposts against any offensive from Samarqand. Marv spearheaded the northern frontier with the Uzbek confederate clans. Nisa, Bavard (or Abivard), and Sarakhs, where two Qājār and Afshār tiyzul-holders had been put in charge of the Safavid forces, were supposed to back up the tiy $\bar{u}$ l-holder stationed in Marv, while tiyzul-holders in Bastam, Damghan, and Jajarm had to attend the task of defending the Safavid territorial conquests in Khurasan against any Uzbek onslaught from Astarabad. But during the period in question, Balkh was the most important tiyūl district in Khurasan. In 916/1510-1511, Ahmad Beg Afshār, who held Sarakhs as tiy $\bar{u} l$, along with the tiy $\bar{u} l$-holders in the western flank of Khurasan had moved their täbin regiments to Balkh to counter the Uzbek forces to the north of Samarqand (E. 8349, reporoduced as document XXV in Fekete 1977, p. 260).

The two other major tiy $\bar{u} l$ land assignments in early Safavid Iran were Shiraz and Baghdad, both contributing an overall amount of about 160 tümāns between 914 and 918/1508 and 1512. Fars had been given as tiyül to the military and tribal chiefs who had joined the Qizilbāsh from the Zu'l-Qadr Emirate in central and southwestern Anatolia.

\section{Monetisation of Tiyūl and the Qizilbāsh Opposition}

The backdrop against which the monetisation of tiy $\bar{u} l$ under Shah Ismā'îl took place was a campaign of fiscal and administrative centralisation initiated in 913/1507-1508 by Najm al-Dīn Mas'ūd Rashtī (d. 915/1509), a goldsmith (zargar) and political fugitive from Gilan-i Biyah Pas at the Safavid court, who was made the shah's vakil or deputy in fiscal affairs late in 913/1508 at the royal winter camp in Hamadan (Khvāndmīr 1333 Sh./1954, Vol. 4, pp. 490-491; Lāhījī 1974, pp. 198, 312, 315; Aubin 1988, pp. 112-113; Rūmlū 1384 Sh./2005, p. 1010). Contemporary narrative sources clarify that upon his promotion to vakil Najm Zargar resolved on restricting the fiscal powers of the Qizilbāsh military chiefs. Underlying his centralising policies were "planned budgeting and systematic book-keeping" or hisāb u kitāb. In particular, he is reported to have been keen on "redressing the disorders that had crippled fiscal administration in several provinces" (Khvāndmīr 1333 Sh./1954, Vol. 4, p. 491; cf. Ghaffārī Qazvīnī 1343 Sh./1964, p. 271; Sayfī Qazvīnī 1386 Sh./2007, p. 280). Najm Zargar's reforms came in the footsteps of three ill-fated campaigns of fiscal and administrative centralisation initiated in Iran at the close of the 15th century under the supervision of the Aqquyunlu vizier 'İsā Sāvajī (d. 896/1491), his Timurid counterpart in Herat 
Majd al-Dīn Muhammad Khvāfī (d. 899/1494), and the Aqquyunlu prince Gövde Ahmad (d. 902/1497). ${ }^{39}$

Shah Ismā'îl's rise to power in the summer of 907/1501 was soon followed by the new regime's double-standard approach to fiscal centralisation. In provinces like Azerbaijan, where the administrative authority of the Qizilbāsh was firm and expansive, it took less than two years for the Safavid bureaucrats to take first steps towards fiscal and administrative centralisation. In Ramadan 909/March 1504 and Shawwal 911/March 1506, a number of Safavid land surveyors were posted to the dominantly Armenian-populated districts of Urdubad, Nakhchivan, and Maku to the north and northwest of Tabriz to inspect the ownership status of agricultural lands and urban properties in the region (documents XI and XIII in Papazian 1956-1968, Vol. 1, pp. 460-463). Another task these bureaucrats were expected to attend to was direct taxation on landed notables in the region. Where it was politically disadvantageous for the new regime to effectuate bureaucratic centralisation, the Safavids opted for fiscal laissez fair and administrative decentralism. In Persian Iraq, for instance, the new regime's policy of putting the locally prominent landed notables in charge of fiscal administration of the province is argued to have bought the shah their muchneeded support and collaboration (Aubin 1959, pp. 50-51). In Khurasan, a hotbed of political and religious opposition to the Qizilbāsh, Shah Ismā‘̄il had no qualms about incentivising land and money to win the backing of local notables irrespective of their confessional leanings. Soon after the conquest of Marv and Herat, he ordered "liberalisation" of all Timurid khālișa or state-owned agricultural lands and urban properties ( $i q \bar{a} r u$ amlāk) so that they could be redistributed as financial expedient among the new regime's allies in the province (Amīnī Haravī 1383 Sh./2004, p. 358).

The contemporary anecdotal accounts on Shah Ismā'îl represent the opening decade of his reign as an era of administrative disorder at court and fiscal excesses in provinces, all attributed to the shah's calculated disinterest in amassing personal wealth, a trait that undid any institutional move toward systematic budgeting and fiscal discipline during the years that ensued immediately following the Qizilbāsh capture of Azerbaijan in 907-908/1501-1503. While a contemporary chronicler underlines the increasing personalisation of career mobility among the new regime's bureaucratic and military recruits, which made all appointments and promotions dependent on the shah's whims and wishes (Sayfĩ Qazvīnī 1386 Sh./2007, p. 289), another late 16thcentury historian points to the shah's lack of interest in micromanaging the fiscal affairs of the state (Qazvīnī 1999, pp. 45-47). Still another observer was baffled by the monetary costs of Shah Ismā'îl's cronyism, clarifying that "no amount of cash in this world" could stand the shah's lavishing money on his intimates and bureaucratic favourites (Simões 1898, p. 243; cf. Jodogne 1980, p. 227). To win the shah's approval and support amid the increasing opposition to his centralising policies among the Qizilbāsh military and tribal chiefs, Najm Zargar had to provide him with as much cash as he could, hence his efforts to cash in on all the basic services of the

\footnotetext{
${ }^{39}$ On these three reform initiatives, see Minorsky (1955, pp. 425-469); Woods (1999, pp. 143-144, 158-159); Paydaş (2004, pp. 205-212); and Subtelny (2007, pp. 89-95).
} 
central government, including tiyül. Fiscal belt-tightening in provinces required all tiyül-holders to pay a fraction of their emoluments to central treasury on annual basis. During his period as vakill, Najm Zargar had managed to extract some 200 tümāns from the tiyull-holders posted to Diyarbakir, Azerbaijan, Persian Iraq, and Fars. Shortly before his death, he is reported to have managed to accumulate a cash reserve of 20,000 tümāns in central treasury (Khvāndmīr 1333 Sh./1954, Vol. 4, p. 491; Aubin 1984, p. 12; Amīnī Haravī 1383 Sh./2004, p. 313).

In the short run, these centralising policies brought profit for the shah, but Najm Zargar's avaricious money mongering polarised political forces at court and in provinces. In particular, tiy $\bar{u} l$-holders resented with direct taxation. Few months after surviving a coup, which took place in the spring of 915/1509 and ended with the shah's intervention on his behalf, Najm Zargar revoked the tiyūl rights and privileges of his foes Abdāl Beg Zu'l-Qadr and Husayn Beg Shāmlū (d. 920/1514), whose mem-

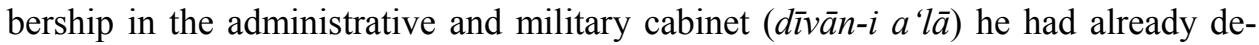
clared void and null (Ghaffārī Qazvīn̄i 1343 Sh./1964, p. 272; Aubin 1988, p. 114; Amīnī Haravī 1383 Sh./2004, p. 313). Najm Zargar died early in the autumn of the same year in Arvanaq (modern Khamina), a rural settlement near Tabriz, under the circumstances that make it plausible to consider his demise a political murder. A dirge by Muhammad Ahlī Shīrāzī (d. 940/1535), an admirer of Najm Zargar, concludes with remarks on the deceased vizier's enemies, blaming his unanticipated death on their "poisonous" thoughts (see ode XLVI/vv. 9642-9664 in Ahlī Shīrāzī 1344 Sh./1965, pp. 471-474).

The next vakīl Yār-Ahmmad Khūzānī (d. 918/1512) was so unrelenting in his pursuit of fiscal centralisation that it earned him the epithet Second Najm or Najm-i thānī. Like his predecessor, Khūzānī acted as amīr al-umārā or chief minister at the administrative and military cabinet (Aubin 1988, p. 117). At the time of his promotion to vakīl, Khūzānī had also been made vizier, which maximised the scope of his authority as head of the fiscal and scribal services of the Safavid bureaucracy (AFT I, ff. $91 \mathrm{r}, 167 \mathrm{r}-\mathrm{v}, 169 \mathrm{v} ; A h T$, ff. $592 \mathrm{r}-\mathrm{v}$ ). In time, Khūzānī’s rise to power sealed the fate of five top members of the ahl-i ikhtișass (lit. bearers of prerogative) ${ }^{40}$ clique: the shah's guardian (lala) and chief of staff (amīr-i dìvāan) Husayn Beg Shāmlū (Ghaffārī Qazvīnī 1343 Sh./1964, pp. 266, 269, 277; Lāhījī 1353 Sh./1974, pp. 186, 262), his adjutant and commander-in-chief of cavalry regiments (qūrchī bāshì) Abdāl Beg Dada Zu'l-Qadr (Khvāndmīr 1333 Sh./1954, Vol. 4, pp. 474-475; Ghaffārī Qazvīn̄̄ 1343 Sh./1964, p. 272), the chief army inspector (tuvāchi bāshī) and the shah's brother-in-law Zayn al-'Ābidīn Beg Shāmlū (d. 912/1506) a.k.a. 'Abdī Beg (Khvāndmīr 1333 Sh./1954, Vol. 4, pp. 479-481; Ghaffārī Qazvīnī 1343 Sh./1964, p. 272; AFT I, f. 122r), the shah's deputy in spiritual affairs (khalīfa) Malik Muzaffar Țālish (d. 920/1514) a.k.a. Khādim Beg Khalīfa (Ghaffārī Qazvīnī 1343 Sh./1964, p. 272; Aubin 1984, pp. 5, 26), and Bayrām Beg Qaramānlū (d. 920/1514), who had married

\footnotetext{
${ }^{40}$ Under Shah Ismā‘îl the ahl-i ikhtișās clique was composed of seventeen high-ranking Qizilbāsh military chiefs; for more on these military chiefs and Khūzān̄’'s opposition to them, see Aubin (1984, pp. 2-3, 11-12).
} 
a sister of Shah Ismā'īl and acted as chief royal equerry (amīr $\bar{a} k h \bar{u} r b \bar{a} s h \bar{\imath})$ (Khvāndmīr 1333 Sh./1954, Vol. 4, pp. 392, 497-498; Husaynī Qumī 1383 Sh./2004, p. 57; AFT I, ff. $102 \mathrm{v}, 112 \mathrm{v}$ ). Needless to say, almost all of these Qizilbāsh emires were tiyūl-holders.

Upon his promotion to vakīl/vizier, Khūzānī brought under his control all "fisscal and administrative affairs of the country" and in less than four years accrued enough money to mobilise an army of 5000 cavalrymen on the occasion of his invasion of Khurasan in 918/1512 (Khvāndmīr 1333 Sh./1954, Vol. 4, p. 527; AFT I, f. 203r; cf. Aubin 1988, pp. 28-36). This stands in clear contrast to what we know about the numerical strength of the tābin forces recruited by the Qizilbāsh tiyūl-holders on the eve of the Battle of Chaldiran in 920/1514, which according to an Ottoman military reconnaissance dispatch did not exceed $3000 q \bar{u} r c h \bar{\imath}$ s or cavalrymen (E. 11996, reproduced in Bacqué-Grammont 1987, pp. 179-181). The new army, whose ranks had swelled to 12,000 recruits towards to the end of Khūzānī's career, represented one of the first steps taken by the Safavid central authorities towards creating a "professional" army, foretokening the introduction and sophistication of the ghulām system of military elite mobility under Ṭahmāsb I (924-984/1524-1576) and 'Abbās I (995-1038/15871629).

So far as tiyūl-holders are concerned, Khūzānī's centralising policies played on their further marginalisation. Less than a year into his appointment as vakil/vizier, the amount extracted from tiyūl-holders had a 300\% rise. The fragmentary evidence given in the Safavid narrative sources on Khūzānī's management of tiyūl affairs between 915/1509 and 918/1512 indicates that he was bent on demilitarising tiy $\bar{u} l$ land assignments in central Iran, hence the relatively small number of the districts enfeoffed as tiyūl with the Qizilbāsh in Persian Iraq between 914/1508 and 918/1512. Early on in his career, Khūzānī is reported to have appointed a paternal cousin of his, a nonQizilbāsh landed notable in Isfahan, as tiyūl-holder in Abarkuh (AFT I, f. 202r), the second most important city in the province of Yazd in the latter part of the 15th century (Hāfiz Abrū 1378 Sh./1999, Vol. 2, p. 111), which once had been given as tiyūl to such a prominent Qizilbāsh military chief as 'Abdī Beg Shāmlū. At the same time, Khūzānī was keen on spending the cash reserves accumulated under his predecessor on nonQizilbāsh cavalry regiments, a move that was aimed to make the shah less dependent on tiyūl-holders and their tābin forces.

The Qizilbāsh resented Khūzānī’s reforms and a number of tiyūl-holders in provinces complained about their insolvency and subsequent inability to take part in the shah's military campaigns. A petition dated from about 916/1510-1511 and signed by the keeper of the royal seal Amīr Beg Mawșillū points to his career instability as a tiyūl-holder during Khūzānī's period as vakill/vizier, criticising those at the helm of central bureaucracy for overtaxing the emoluments of provincial tiy $\bar{u} l$-holders of his ilk. In particular, Amīr Beg criticised central authorities for their excesses in taxing his meager earnings from a tiyūl district in Khurasan in 916/1510-1511, which had recently been plundered by the Uzbeks. He urged the shah to either lower the tax rate or allow him to lay off part of his personal retainers so that he could mount a wellorganised army of tābins at the time of general mobilisation or jār u yasāq (E. 12212; 
Aubin 1988, p. 31). Similarly, another petition prepared on behalf of the Safavid military governor of Shaburghan to the east of Balkh points to the disorderly nature of the disposal of tiyül land assignments in Khurasan as well as to the heavy costs of keeping on duty nökar forces along the eastern flank of the province (E. 5835, document XXXIV in Fekete 1977, pp. 255-258). The same problems prompted the Safavid tiy $\bar{u}$-holders in Balkh and its neighbouring rural settlements to petition to the shah in 916/1510-1511, asking him to reconsider the practice of direct taxation (E. 8316; cf. Fekete 1977, pp. 263-265). During this period, the outbreak of famine and depopulation of many urban and rural settlements in Khurasan prevented provincial tiy $\bar{u}$-holders in eastern Iran to pay the pre-determined imposts (E. 5835, document XXXVIII in Fekete 1977, pp. 269-270).

It was as a result of these fiscal and disorganisation pressures that late in the autumn 918/1512, the Khurasan-based Qizilbāsh tiyūl-holders deserted the armies led by Khūzānī during a major campaign against the Uzbeks, leaving him alone with his death in the hands of the Uzbeks at the fortress of Ghijduvān few miles to the north of Marv (Khvāndmīr 1333 Sh./1954, Vol. 4, pp. 523-524; Szuppe 1992, p. 82).

\section{Concluding Comments}

Between 914 and 918/1508 and 1512 more than eighty rural and urban districts across the Safavid dominions in Iran and eastern Anatolia were administered as tiy $\bar{u} l$ land assignment under the supervision of the Qizilbāsh military and tribal chiefs. These tiy $\bar{u} l$-holders paid a portion of their emoluments to central treasury. The total amount of the taxes collected from them during these four fiscal years did not go beyond one tenth of central treasury's cash flow in one fiscal year. Therefore, it is safe to conclude that more than its monetary value, the disposal of tiyu $\bar{l}$ land assignments acted as a mechanism of administrative control. In the provinces of Azerbaijan, Persian Iraq, Fars, Arabian Iraq, and Kirman, the tiy $\bar{u} l$ system of land tenure provided for the new regime to boost its control over fiscal administration. The most productive tiyullholders in early Safavid Iran had been stationed in Persian Iraq, contributing 23\% of the taxes levied on and collected from tiy $\bar{u} l$-holders across the country. Overall, the amounts extracted from the tiy $\bar{u} l$-holders posted to Khurasan and Azerbaijan added up to $37 \%$ of the shah's share of the income from direct taxation on tiyül-holders' annual emoluments. Less than a quarter of the shah's income from the taxes collected from tiy $\bar{u}$-holders came from Fars, Kerman, Arabian Iraq, Luristan, and the Kalhur District.

In Diyarbakir, where over the course of four fiscal years tiy $\bar{u} l$-holders had deposited as tax more than 125 tümāns of their emoluments with central treasury, tiyzūl expedited the process of dynastic transition in the Kurdish city-states of eastern Anatolia. The appointment of tiyzul-holders in Hazo, Hizan, Palu, Kulb, Çemişgezek, Çermik, Atak, Hisnkeyf, and Siirt between 914 and 918/1508 and 1512 brought about the downfall of local powerbrokers and ruling families. Most of these marginalised local elites were former allies of the Aqquyunlu and in the latter part of the 15th cen- 
tury had supported them against the Ottomans. As a result, their elimination in the years leading up to Selim I's invasion of Tabriz in the summer of 914/1520 left Shah Ismā‘ 1 ll with no reliable regional allies. In 916/1522, many of these locally prominent emirs and bureaucrats backed the Ottomans in their struggle against the Safavid forces in eastern Anatolia in the Battle of Eski Koç Hisar, which resulted in the separation of the province of Diyarbakir from Safavid Iran.

Only a small fraction (between 3 and 10\%) of a tiyūl-holder's annual emolument was subject to direct taxation, but in 916/1510-1511 there had been a $300 \%$ spike in the overall amounts collected from tiy $\bar{u}$-holders across the country. This resulted in the disgruntlement of a number of tiyül-holders. In particular, those tiy $\bar{u}$-holders who had been posted to Khurasan were vocal in expressing their dissatisfaction with the way in which tiy $\bar{u} l$ affairs of the country were handled under the supervision of the shah's vakīl/vizier Yār-Aḥmad Khūzānī. The controversy over the mismanagement of tiy $\bar{u} l$ epitomised the internal power crisis that engulfed the Safavid state on the eve of the Battle of Chaldiran, ushering in a decade that witnessed major territorial loses in the eastern and western flanks of the country.

\section{Appendix}

$\mathrm{He}$

THE RECEIPT OF THE SHAH'S SHARE OF THE INCOME FROM TIYŪL [DISTRICTS] IN ITS TRANSCRIPT [VERSION], 730 TUUMĀNS AND 6000 DINARS $[\text { sic }]^{41}$

\section{YEAR OF THE DRAGON}

Empty

\section{YEAR OF THE SNAKE}

100 tümāns and 4000 dinars

\section{Diyarbakir}

9 tūmāns and 1000 dinars

Harput as tiyūl of böy nökar 5 tūmāns

Savur as tiȳūl of Husayn Beg Shāmlū 2 tūmāns and 5000 dinars

Çüngüş and its fortress as tiyūl of Khalīl Beg 6000 dinars

Çermik as tiyyūl of Qulī Khalīfa Shāmlū 1 tūmān

\footnotetext{
${ }^{41}$ The correct amount is 730 tümāns and 4000 dinars.
} 


\section{Azerbaijan}

32 tūmāns and 1000 dinars

Ganja as tìyūl of Dāna Beg 7 tūmāns and 2000 dinars

Khuy as the fodder tiȳūl of Durmush Beg 1 tümān and 2000 dinars

Varanda and Dizaq, etc., as tìyūl of Pīrī Beg Qājār 5 tūmāns

Turkmens of Qarabagh, etc., as tiyūl of the same community 5 tümāns

Bargushat etc., as tiyūl of Uğurlu Mīrzā 8 tūmāns

Garmrud as tiyūl of Shahvirdī Beg 1 tūmān and 2000 dinars

Maragha as tiyūl of 'Alī Beg Halvāchī-Uğlī 2 tūmāns

Sarab as tiyūl of Khush-Andām Beg 2 tūmāns

Arut as the fodder tiy $\bar{u} l$ of Lala Beg 5000 dinars

\section{Persian Iraq}

38 tūmāns and 2000 dinars

Hamadan as tiyūl of Yigān Beg Tekkelū et al., 6 tūmāns

Ray as tiyūl of Dīv Beg 7 tūmāns

Qazvin as tiyūl of Dada Beg 5 tūmāns

Shahryar as tiyyul of Pīr Aḥmad Beg Varsāq 4 tūmāns and 2000 dinars

Qum as tiyū $l$ of Lala Beg 5 tümāns

Isfahan as tiyūl of Durmush Beg tuvāchī 7 tūmāns

Natanz as tiyūl of Nārīn Beg 4 tūmāns

\section{Arabian Iraq}

As tiyūl of Khulafā Beg Qaramānī 30 tūmāns

\section{YEAR OF THE HORSE}

80 tūmāns and 9000 dinars $[\text { sic }]^{42}$

\section{Diyarbakir}

25 tūmāns and 2000 dinars $[\text { sic }]^{43}$

Çemişgezek as tiyūl of Rustam Beg 8 tümāns

Harput as tiyūl of Ayğūd-Uğli 9 tūmāns

Ebu Tahir and its fortress as tiyūl of Murād Beg Zu'l-Qadr 1 tūmān and 5000 dinars

Ataq as the fodder tiy $\bar{u} l$ of Lala Beg 1 tūmān

Çüngüş and its fortress as tiyūl of Hasan Beg Zu'l-Qadrlū 9000 dinars

\footnotetext{
${ }^{42}$ The correct amount is 78 tūmāns and 7000 dinars.

${ }^{43}$ The correct amount is 23 tūmāns.
} 
Ruha as tiyūl of Turmush Beg 1 tūmān and 8000 dinars

Siirt as tiyūl of Nārīn Beg 8000 dinars

\section{Azerbaijan}

23 tümāns and 7000 dinars

Chukhur-i Sa'd as tìyūl of Shah 'Alī Beg 7 tūmāns

Mughanat as tiyūl of Bayrām Beg 8 tūmāns

Dihkhvaraqan as tiyūl of Sārū Shaykh 1 tūmān and 2000 dinars

Salmas as tiyūl of Hasan Beg Tekkelu 1 tümāns and 2000 dinars

Urmia as tiy $\bar{u} l$ of the same person 4 tümāns

Ungud as tìyūl of Shah Manșūr Beg 1 tūmān and 3000 dinars

Sarab as tìyūl of Khush-Andām Beg 1 tūmān

\section{Arabian Iraq}

\section{3 tūmāns}

Qazvin as tiyūl of Zaynāl Beg 7 tūmāns

Isfahan as the shared tiy $\bar{u} l$ of Lala Beg 7 tümāns

Qum as the fodder tiyūl of Lala Beg 5 tümāns

Sava as tiyūl of Manșūr Beg qaychāchī

\section{Fars}

As tiyūl of the Zu'l-Qadrlū emirs 9 tümāns

\section{YEAR OF THE SHEEP}

331 tūmāns and 2000 dinars $[\text { sic }]^{44}$

\section{Diyarbakir}

28 tümāns and 4000 dinars $[\text { sic }]^{45}$

The well-guarded Ruha as tiȳul of Turmush Beg et al., 2 tūmāns Talguran as tiyūl of Aḥmad Beg Iğdir 1 tūmān

Hazo, etc., as $u l k \bar{a}$ of 'Alī Beg Sāsānī 1 tūmān and 5000 dinars

Harput as tiyūl of Sārū Shaykh 13 tūmāns

Hisnkeyf as tiyūl of Qarā Beg 4 tūmāns and 2000 dinars

\footnotetext{
${ }^{44}$ The correct amount is 339 tümāns and 9000 dinars.

${ }^{45}$ The correct amount is 33 tümāns and 4000 dinars.
} 
Arabgir as tiyūl of Kurd 'Alī Beg and Qazzāq Beg 7 tūmāns and 7000 dinars Bayburt, etc., as tiyūl of Maqșūd Beg Chapnī 4 tümāns

\section{Azerbaijan}

\section{5 tūmāns}

Usku as tiy $\bar{u} l$ of the same community 1 tümān

Turkmens as tiyūl of the community's military chief 8000 dinars

Miyanduab and Ushni, etc., 1 tūmān and 5000 dinars

Khalkhal as tiyūl of Jalāl al-Dīn Ṭālish 2 tūmāns

Tarumayn as tiy $\bar{u} l$ of the same person 2 tümāns

Urmia as tiyūl of Yigān Beg and Charkas Hasan 13 tūmāns

Dizaq and Varanda, etc., as tiyūl of Pīrī Beg Qājār 4 tūmāans and 2000 dinars

Turkmens of Sarab as tiyzūl of Khush-Andām Beg 5000 dinars

\section{Persian Iraq}

69 tümāns and 7000 dinars

Qum as the fodder tiyyūl of Durmush Beg 24 tümāns

Ray and Simnan as tiyūl of Dīv Beg 9 tūmāns and 5000 dinars

Shahryar and Damavand, etc., as tiyūul of Maḥmūd Beg Varsāq 5 tūmāns

Sultaniyya as tiyūl of Aḥmad Beg Zu'l-Qadr 7 tümāns

Hamadan as tiyūl of Yigān Beg and 'Alī Khan Beg 16 tūmāns

Darjazin as tiyūl of 'Alī Beg ishīk āqāsī 1 tūmānn and 2000 dinars

The Sa'idi Arabs as the fodder tiyūl of Lala Beg 7 tümāns

\section{Fars and Kirman}

58 tümāns and 4000 dinars

Fars as tiyūl of Zu'l-Qadr and Rūmlū emirs 45 tūmāns

Kirman as tiyūl of Ahmmad Beg 13 tümāns and 4000 dinars

\section{Khurasan}

153 tūmāns and 4000 dinars

Herat as tiyūl of Lala Beg 6 tümāns

Balkh as tiyūl of Bayrām Beg 7 tümāns

Sarakhs as tiyūl Aḥmad Beg Afshār 14 tūmāns

Sabzivar, Damghan, and Bastam as tiyūl of Dīv Beg 23 tūmāns

Mazar and Shaflan, etc., as tiyūl of Ḥasan Beg Ḥajīlar 28 tūmāns

Bakhazr as ulkā of Dāna Beg 13 tümāns

Khvaf as tiyūl of Manșūr Beg Afshār 7 tūmāns 
Haratrud etc., as ulkā of Shah 'Alī Beg 11 tūmānns and 4000 dinars

Nisa and Bavard as tiyyūl of Nārīn Beg 3 tümāns

Marv as tiyūl of Lala Beg 14 tūmāns

Mashhad as tiyūl of Zayn al-'Ābidīn Beg 13 tümāns

Turshiz etc., as tiyūl of Durmush Beg 14 tümāns

\section{YEAR OF THE MONKEY}

200 tūmāns and 4000 dinars

\section{Diyarbakir}

51 tümāns and 5000 dinars

Çemişgezek as tiyūl of Ḥasan Beg Tekkelū 14 tümāns

Amid and Mardin, etc., as tiyyūl of Chiyān Beg tuvāchī 7 tūmāns

Erzincan and Kemah as tiyūul of Maḥmud Beg Varsāq 15 tūmāns

Harput as tiyyūl of Sārū Shaykh registered under Year of the Sheep

Hizan as tiyzūl of Dāvūd Beg 5 tūmāns

Arabgir as tiyūl of Asilmas Beg 2 tūmāns

Van and Vustan as tiyūl of Hasan Beg Tekkelū 6 tümāns and 2000 dinars, which is not included in this year

Fortress of Makuya and Bayezid, registered under Azerbaijan

Ergani as tiyūl of Hasan Beg, Muhammadī Beg's brother, 5 tūmāns

Haçuk and Çapakçur as tiyyul of Ḥasan Beg Ayğūd 2 tümānns and 5000 dinars

Palu as tiyyūl of 'Arab Beg 1 tümān

\section{Azerbaijan}

44 tūmāns and 2000 dinars

Mughanat as tiyūl of A ğzivār Beg 13 tūmāns

Sarab as tiyūl of Khush-Andām Beg 1 tūmān and 5000 dinars

Bargushat as tiyūl of Uğurlū Mīrzā 9 tūmāns

Garmrud as tiyūl of Shāhvirdī Beg 1 tūmān

Ganja as ulka of Tarkhān Beg 5 tūmāns

Maragha as tiyūl of 'Alī Beg et al., 4 tūmāns

Fortress of Bayezid and Makuya as tiyūl of Asilmas Beg 1 tūmān and 8000 dinars

Ahlat and Adelcevaz as tiyȳul of Ahmad Beg Zu'l-Qadr 2 tümāns and 7000 dinars

Eleşkirt as tiyūul of Khalīl Beg yasāvul 1 tūmān

Kulb as tiyūl of 'Alī Beg ishīk āqāà̄ 5 tūmānns and 2000 dinars

\section{Persian Iraq}

36 tūmāns and 3000 dinars

Isfahan as tiyzūl of Muhammad Beg emir of the dīvān 15 tümāns 
Shamiran, Shahryar, and Damavand as tiyūl of Maḥmūd Beg Varsāq 7 tūmāns and 8000 dinars

Sultaniyya as tiyūl of Burun Beg töshmāl 4 tūmāns

Tarumayn as tiyȳul of Jalāl al-Dīn Beg 2 tūmāns and 5000 dinars

Khurramabad as tiyūl of Katkhüdā Rustam's Lala in Qara-Ulus 7 tümāns

\section{Arabian Iraq}

45 tūmāns and 2000 dinars

\section{Shiraz}

19 tümāns and 2000 dinars

As tiyūl of Khalīl Beg Zu'l-Qadr 15 tūmāns

As tiyūl of Ḥasan-'Alī Beg Fīl-Qich 4000 tūmāns and 2000 dinars

\section{Kalhur, etc.}

As tiyūl of Bakhshī Beg Kalhur of Qara-Ulus 6 tūmāns

\section{YEAR OF THE COCK}

Empty

AND THE REST FROM THE PAY VOUCHERS ISSUED IN THE NAME OF MILITARY CHIEFS IN YEAR OF THE HORSE, 75 TÜMĀNS AND 8000 DINARS

\section{Jam 7 tümāns}

Sarakhs 8 tūmāns

Badghis 15 tūmāns and 4000 dinars

Mashhad and Nishabur as ulkā of Zaynāl Beg's brother 18 tūmāns

Qa'in as $u l k \bar{a}$ of Amīr Beg and his relatives 13 tümāns and 4000 dinars

Farah the amount deposited during 'Alī Beg's tenure 13 tümāns

Isfarayin and Jajarm 8 tūmāns

Sabzivar as tiyyūl of Dīv Beg 5 tūmāns 


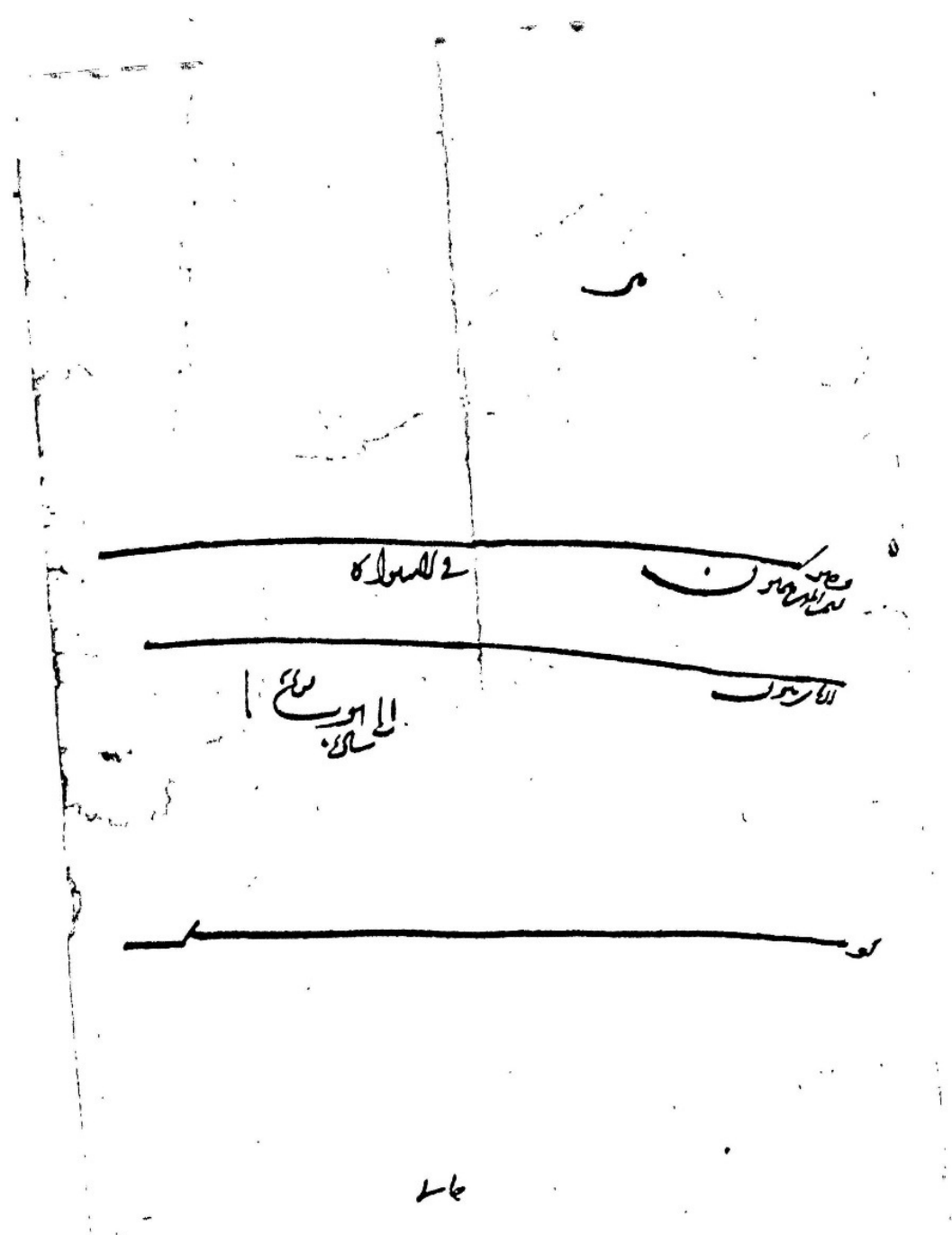

E. 1071 (Topkap1 Palace Museum Archives, Istanbul), f. 1r. 


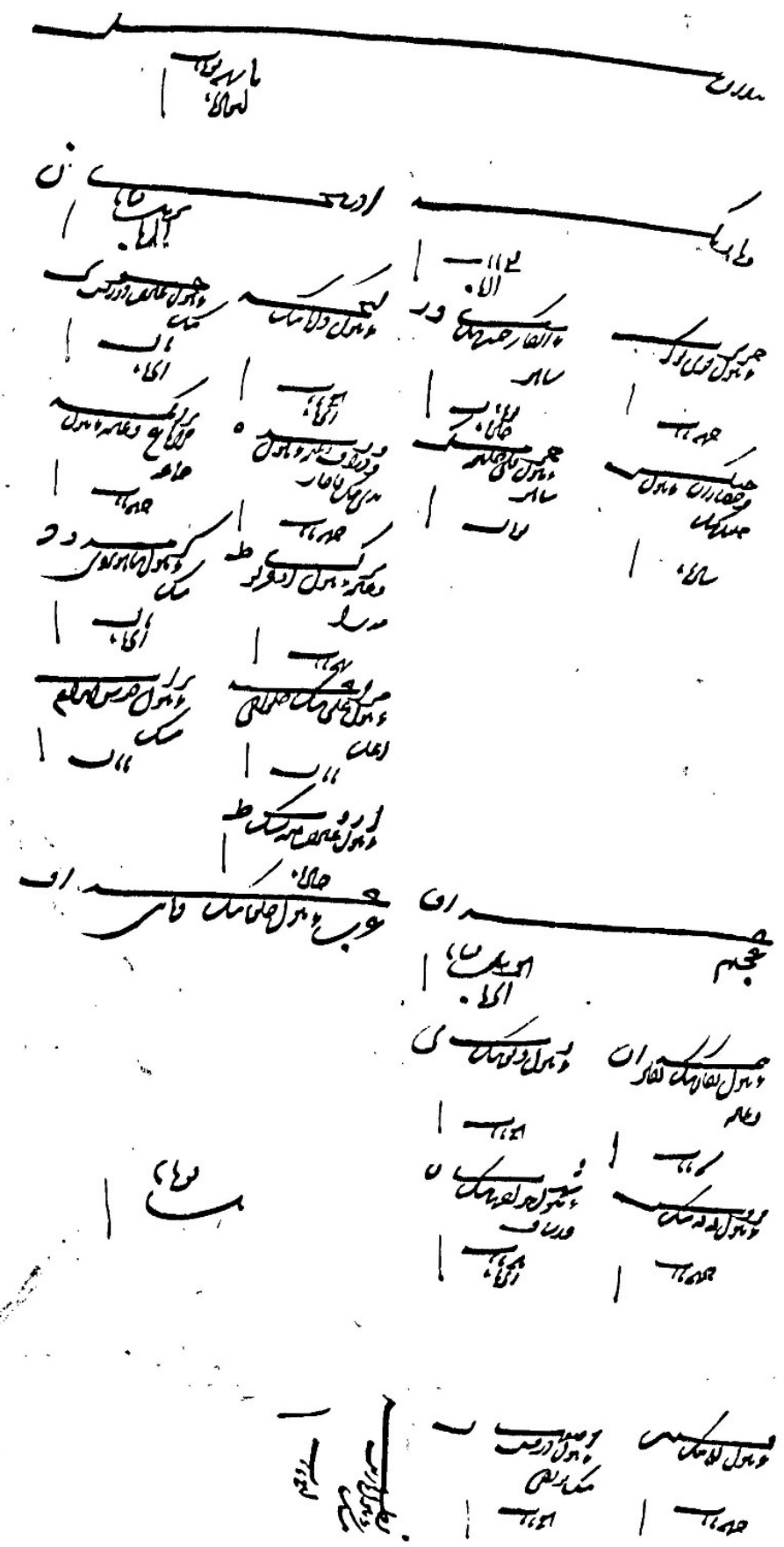

E. 1071 (Topkap1 Palace Museum Archives, Istanbul), f. 1v. 


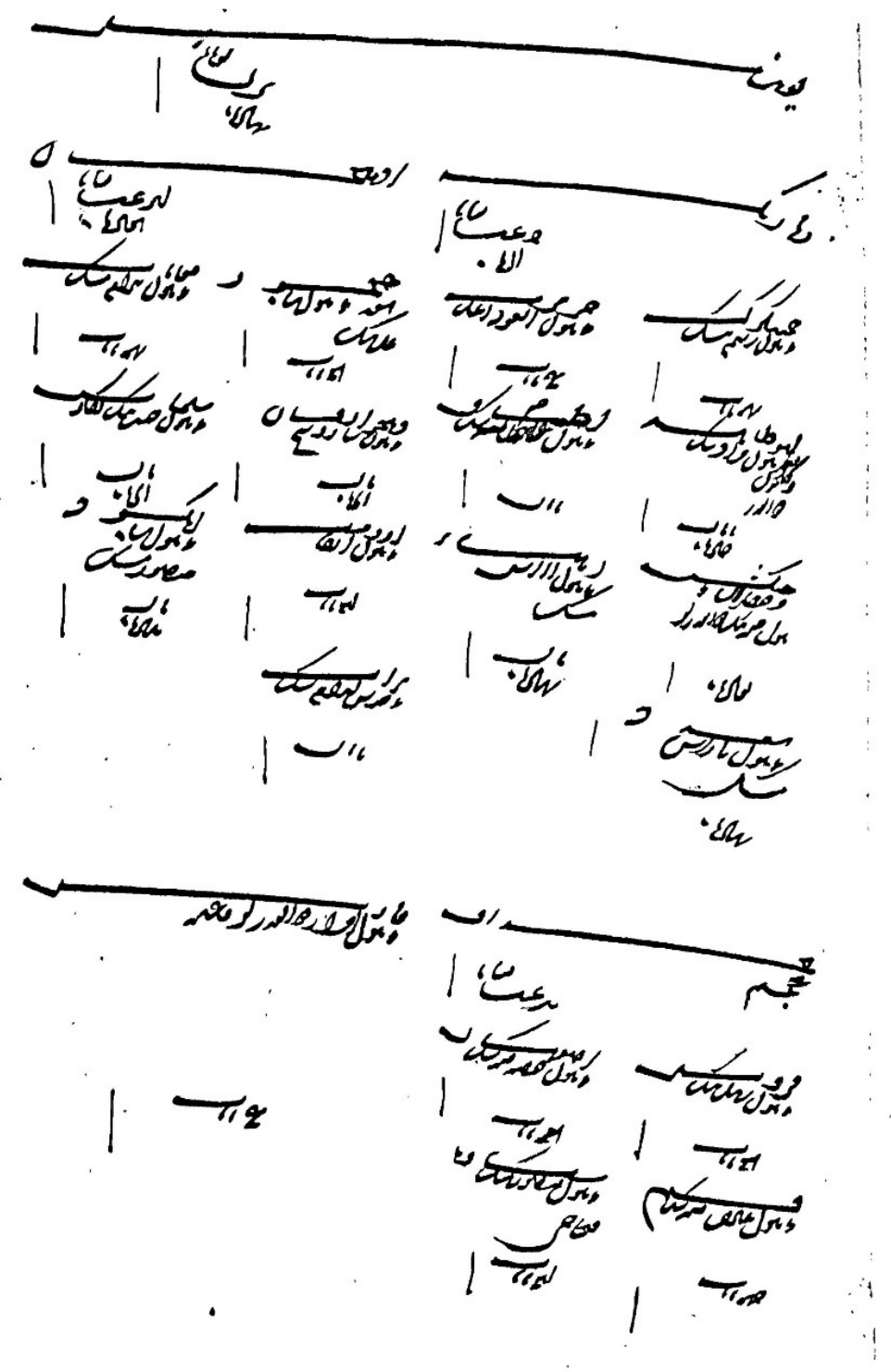

E. 1071 (Topkapı Palace Museum Archives, Istanbul), f. 2r. 


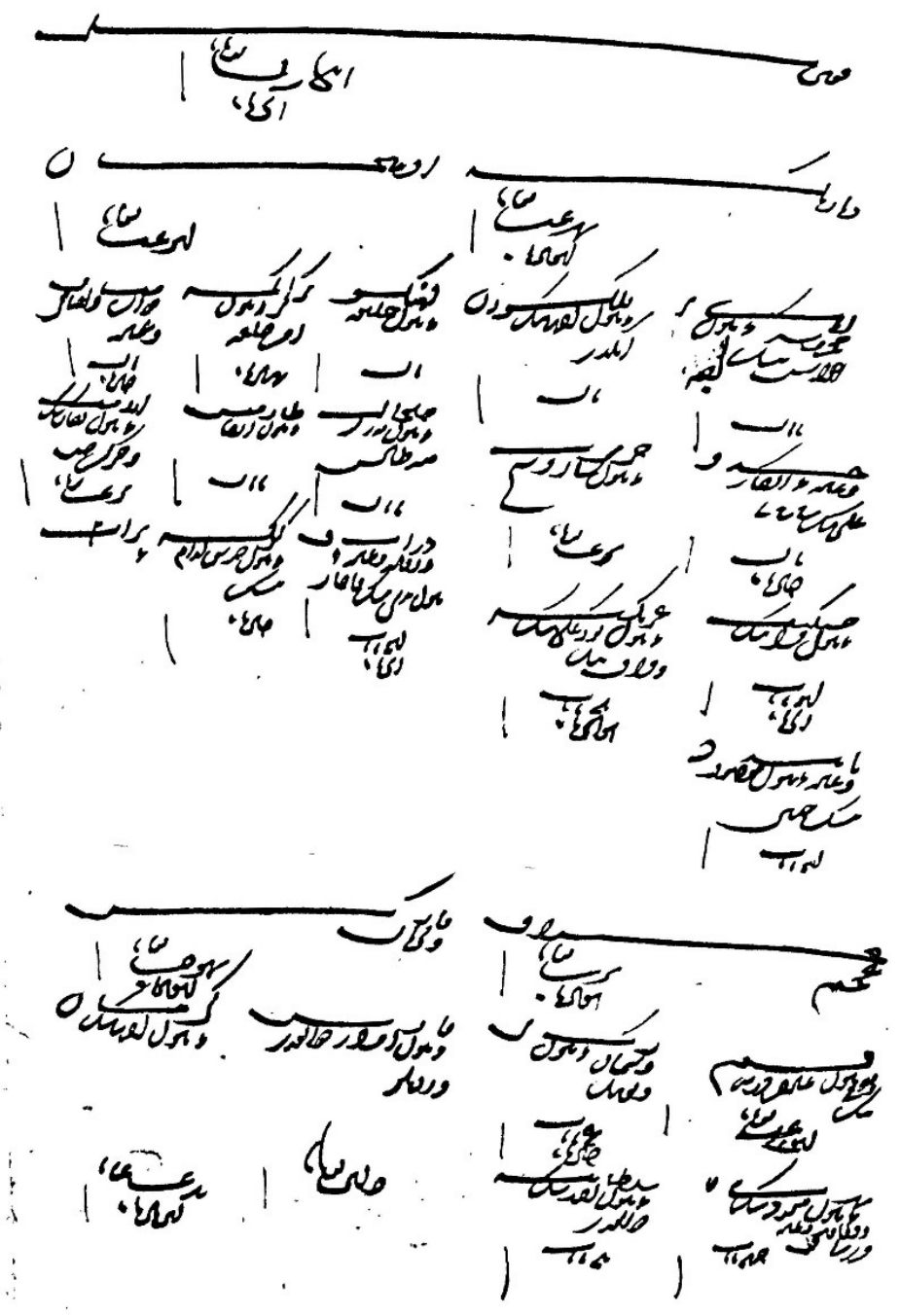

E. 1071 (Topkapı Palace Museum Archives, Istanbul), f. 2v. 

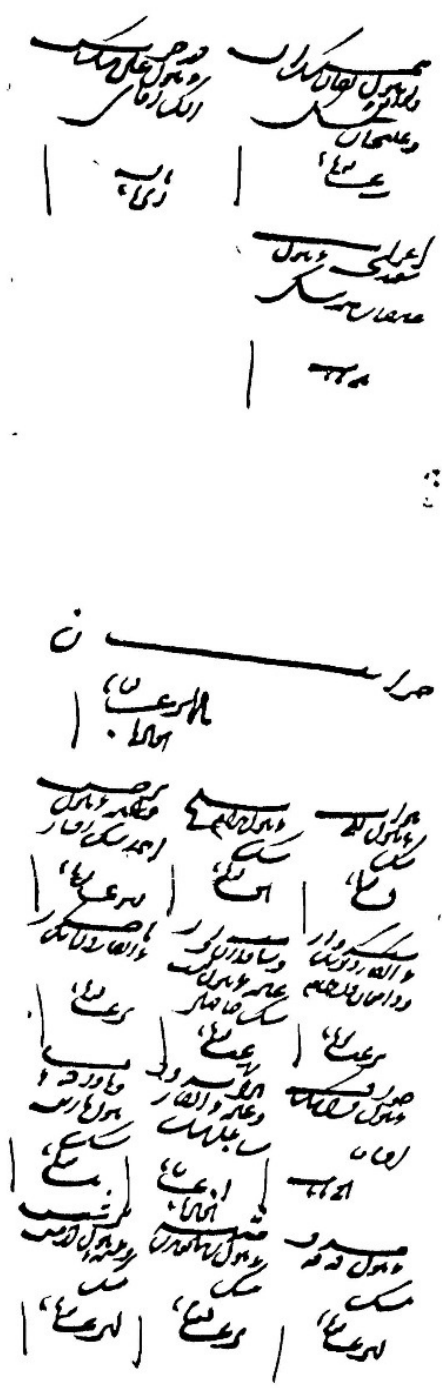

E. 1071 (Topkapı Palace Museum Archives, Istanbul), f. 3r. 

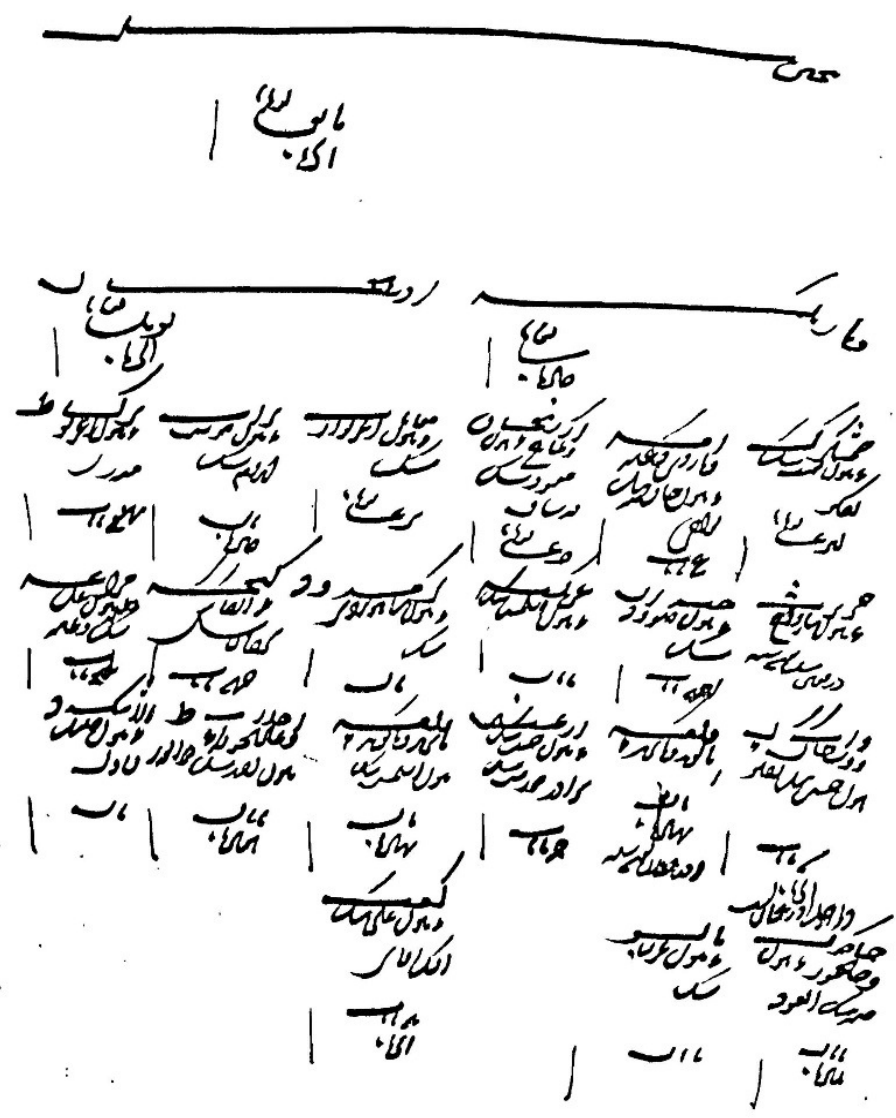

E. 1071 (Topkapı Palace Museum Archives, Istanbul), f. 3v. 


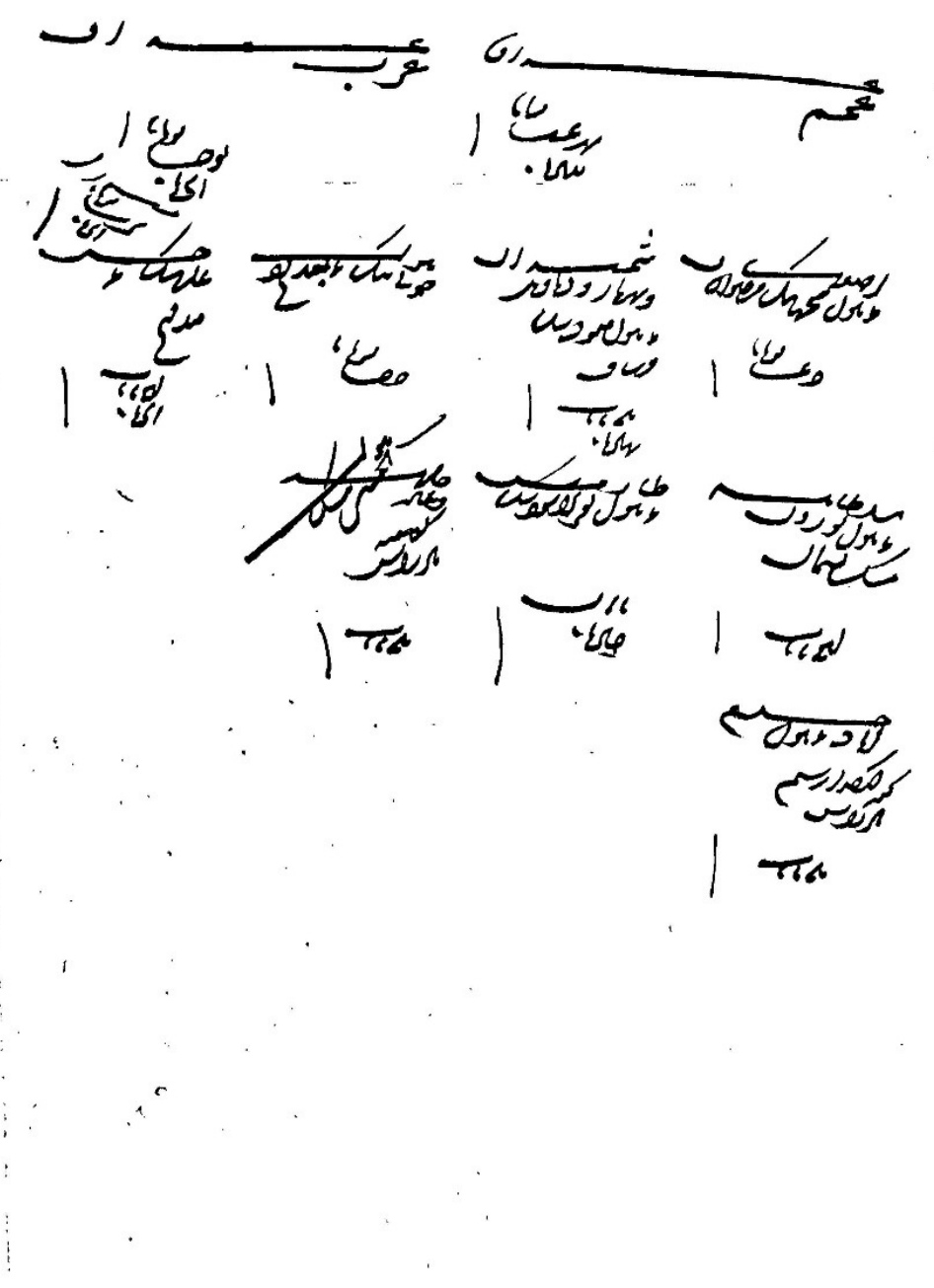

E. 1071 (Topkapı Palace Museum Archives, Istanbul), f. 4r. 

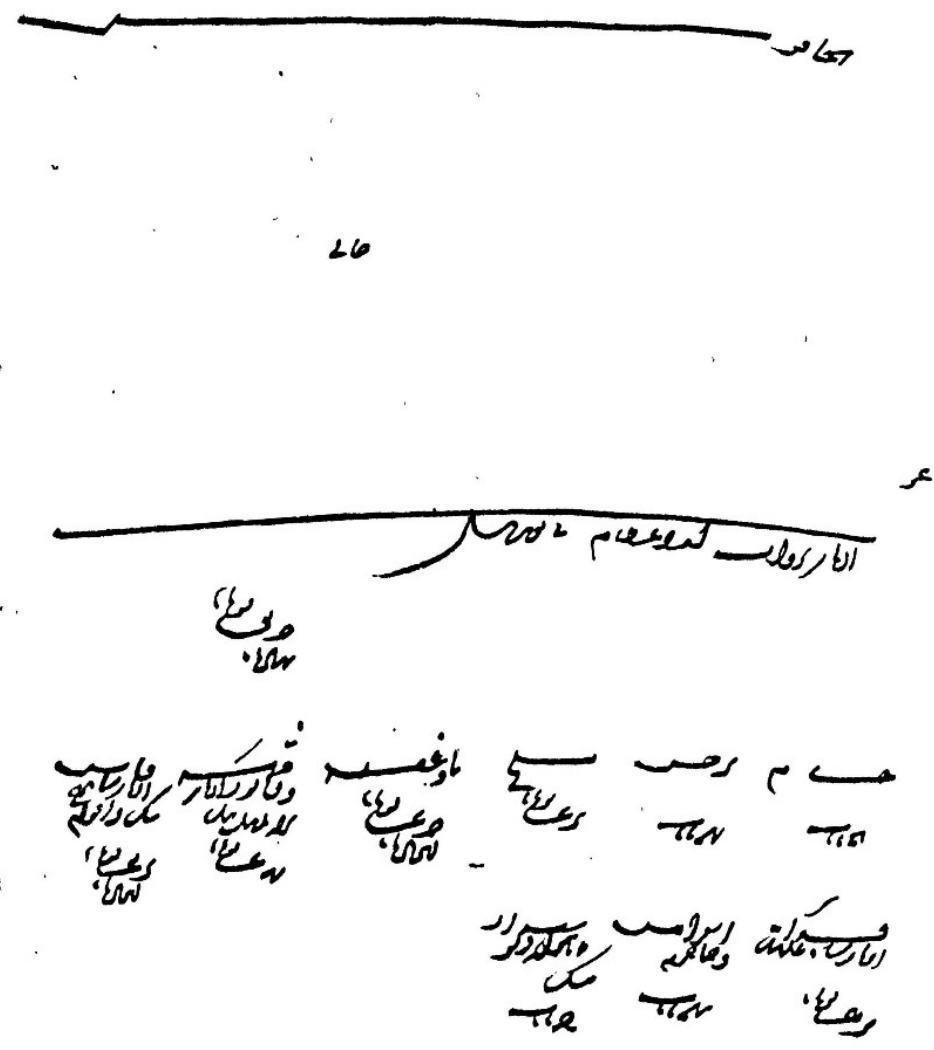

E. 1071 (Topkapı Palace Museum Archives, Istanbul), f. 4v. 


\section{هو}

وصول سهم الملك همايون از بابت تيول فى السو اده

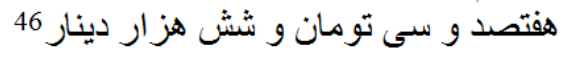

$$
\text { لوى ئيل }
$$

ئيلان ئيل

صد و نه تومان و جهار هز اريل دينار

$$
\text { دياربكر }
$$

نه تومان و يكى هز ار دينار

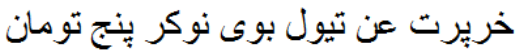

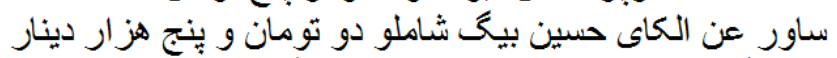

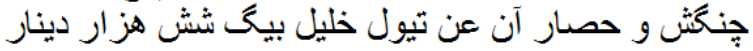

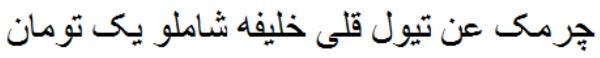

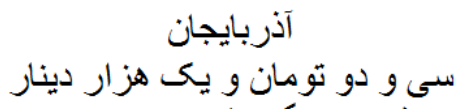

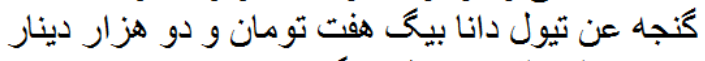

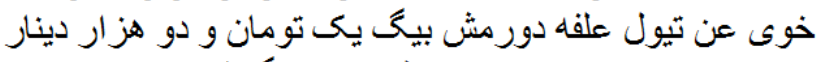

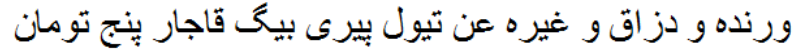

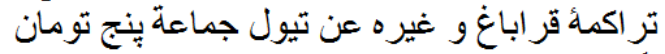

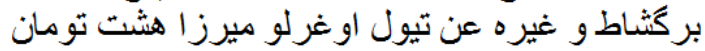

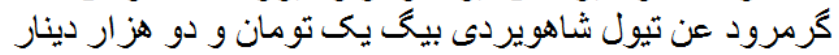

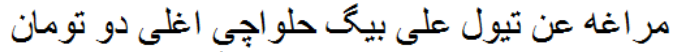

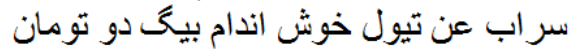

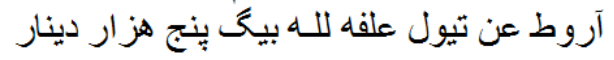

$$
\begin{aligned}
& \text { عراق عجم } \\
& \text { سى و هشت تومان و دو هز هز ار دينار }
\end{aligned}
$$

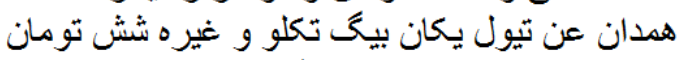

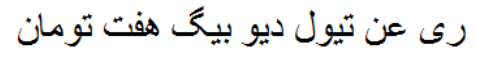

\footnotetext{
${ }^{46}$ Sic.; it must be read 730 tūmāns and 4000 dinars.
} 


$$
\begin{aligned}
& \text { قزوين عن تيول ده ده بيخـ بينج تو مان }
\end{aligned}
$$

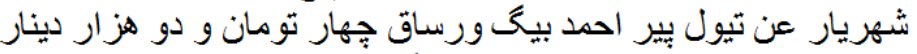

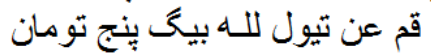

$$
\begin{aligned}
& \text { اصفهان عن تيول درمش بيخ تو اجيى هفت تئت تومان }
\end{aligned}
$$

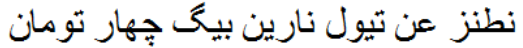

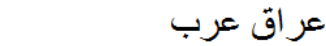

$$
\begin{aligned}
& \text { عن تيول خلفا بيح قرمانى سى تومان } \\
& \text { يونت نيل تيل } \\
& \text { هشتاد تومان و نه هز ار دينار } 47 \\
& \text { دياربكر } \\
& \text { بيست و ينج تومان و دو هز ار دينار } 48
\end{aligned}
$$

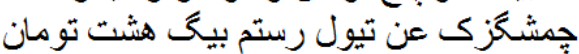

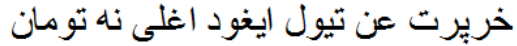

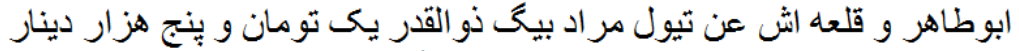

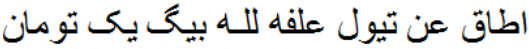

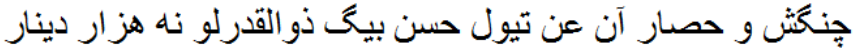

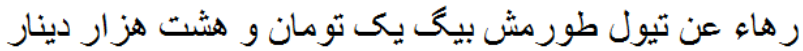

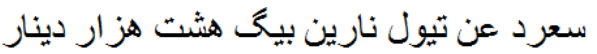

$$
\begin{aligned}
& \text { آذربايجان } \\
& \text { بيست و ساه تومان و هفت هز ارن دئت دينار }
\end{aligned}
$$

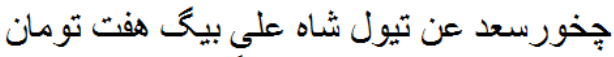

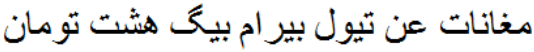

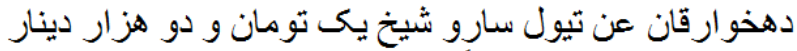

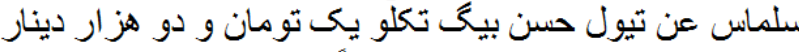

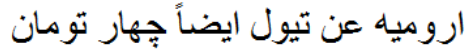

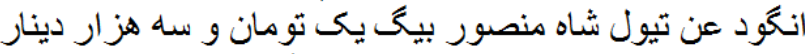

$$
\begin{aligned}
& \text { سر اب عن تيول خوش اندام بيحـ يكـ تومان }
\end{aligned}
$$

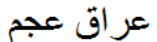

$$
\begin{aligned}
& \text { بيست و سها تومان }
\end{aligned}
$$

${ }^{47}$ Sic.; it must be read 78 tūmāns and 7000 dinars.

${ }^{48}$ Sic.; it must be read 23 tūmāns. 


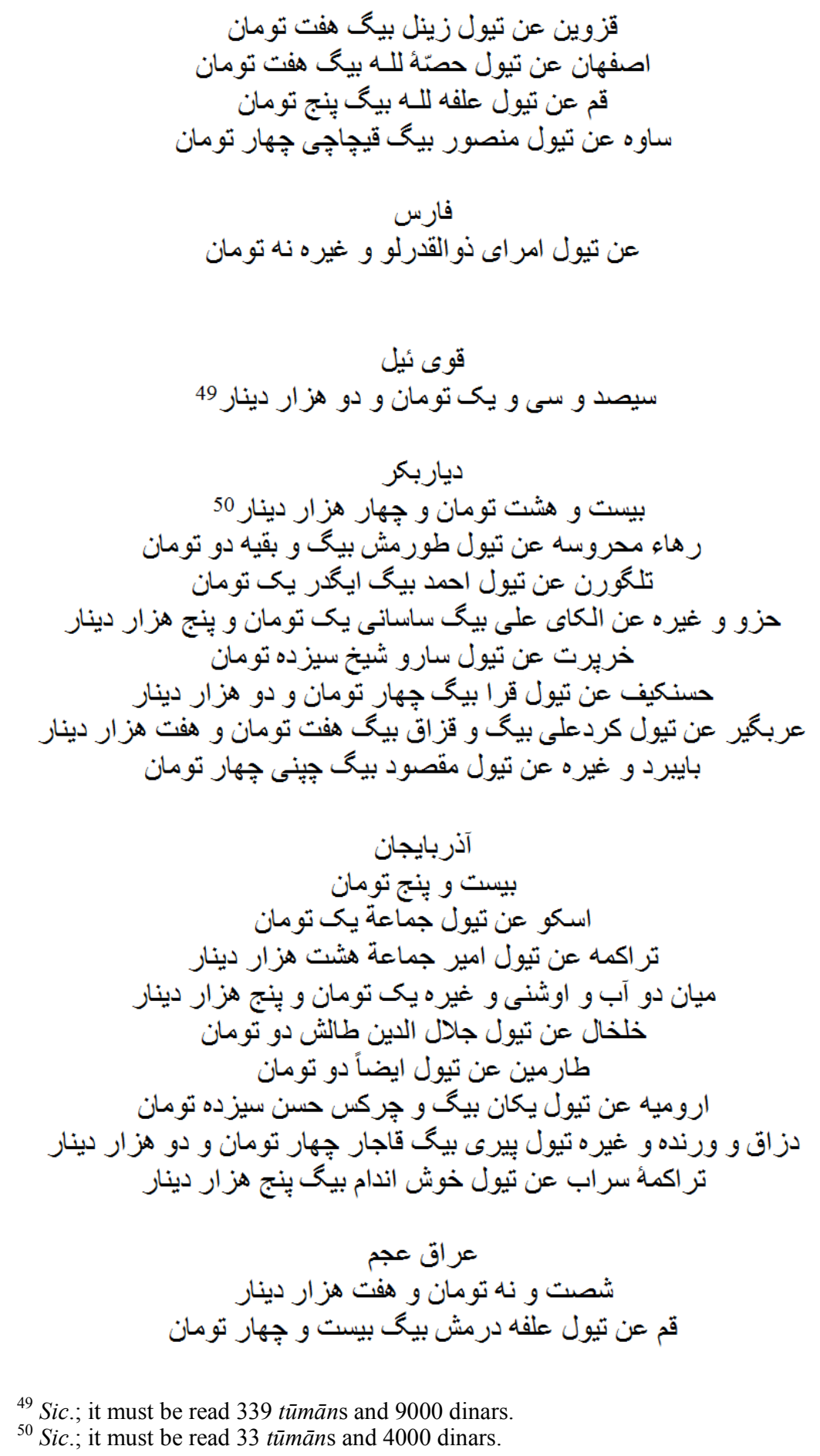


رى و سمنان عن تيول ديو بيح نها تومان و ينج هزار دينار

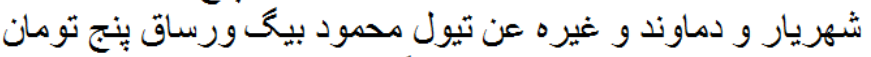

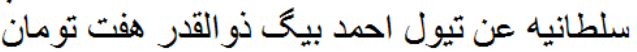

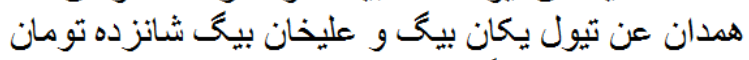

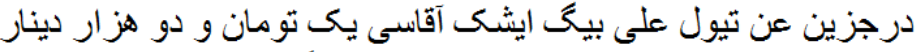
اعر اب سعيدى عن تيول علفه للـه بيى هفت تئت تومان

$$
\begin{aligned}
& \text { فارس و كرمان } \\
& \text { يُنجاه و هشت تومان و جهار هز ار دينار }
\end{aligned}
$$

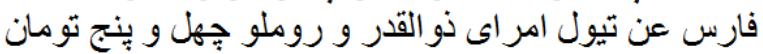

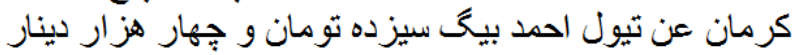

$$
\text { خر استان }
$$

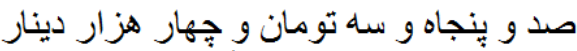

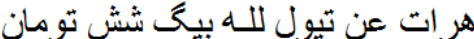

$$
\begin{aligned}
& \text { بلخ عن تيول بير ام بيخ هفت تئ تو مان تومان }
\end{aligned}
$$

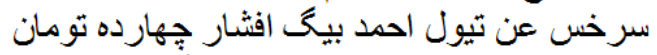

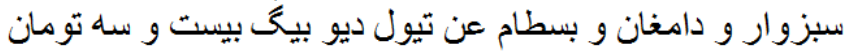

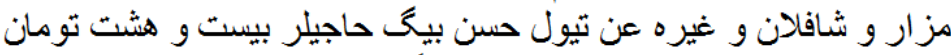

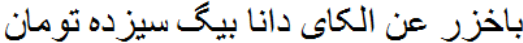

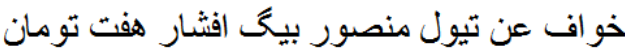

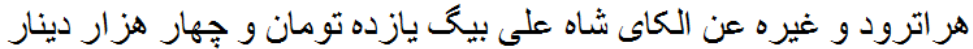

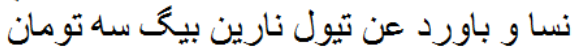

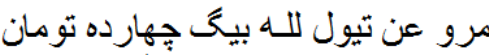

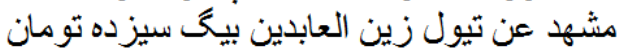

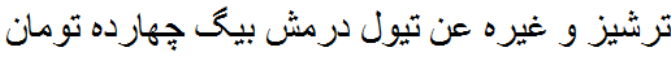

بيجنين ئيل

دويست و دو تومان و جهار هزار دينار

دياربكر

ينجاه و يكى تو مان و بينج هزار دينار

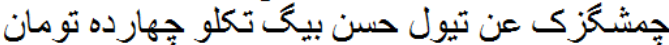

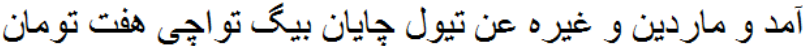

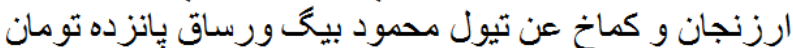

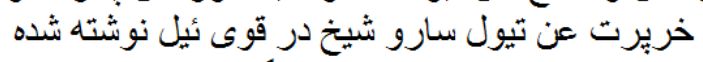

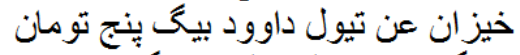

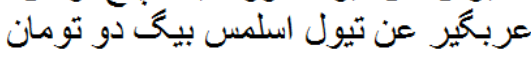


وان و وسطان عن تيول حسن بيح تكلو شش تو مان و دو هزار دينار داخل در اين سال نيست

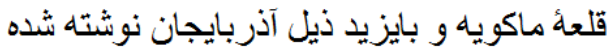

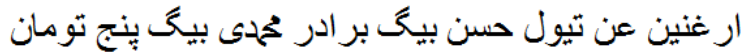

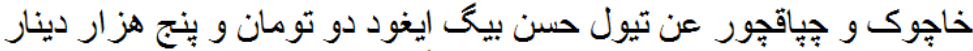

يالو عن تيول عرب بيخى يك تو مان

آذربايجان

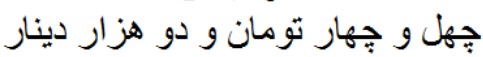

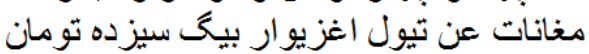

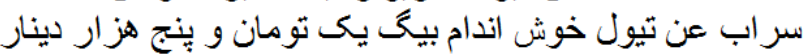

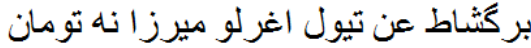

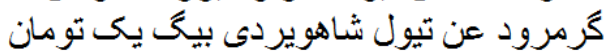

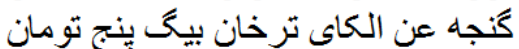

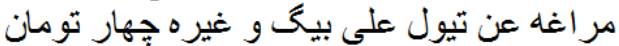

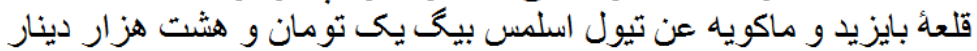

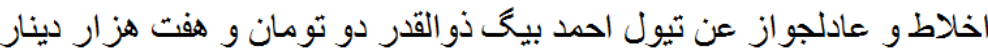

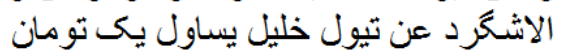

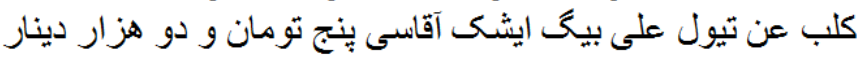

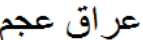

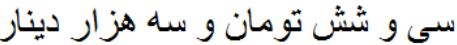

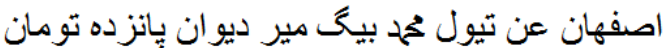

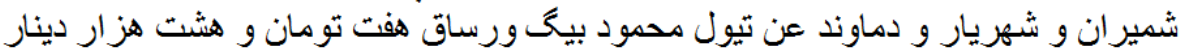

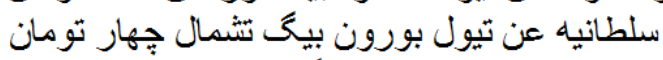

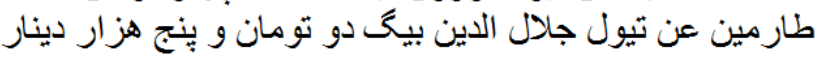

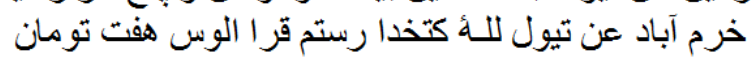

عر اق عرب

جهل و بينج تومان و دو هزات دينار

شير از موز

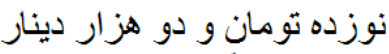

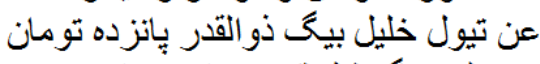

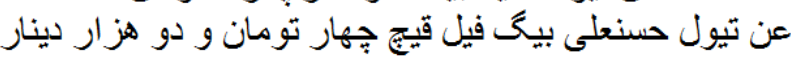

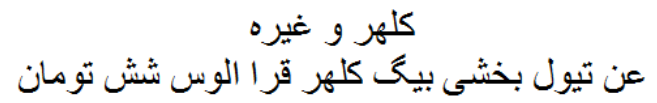




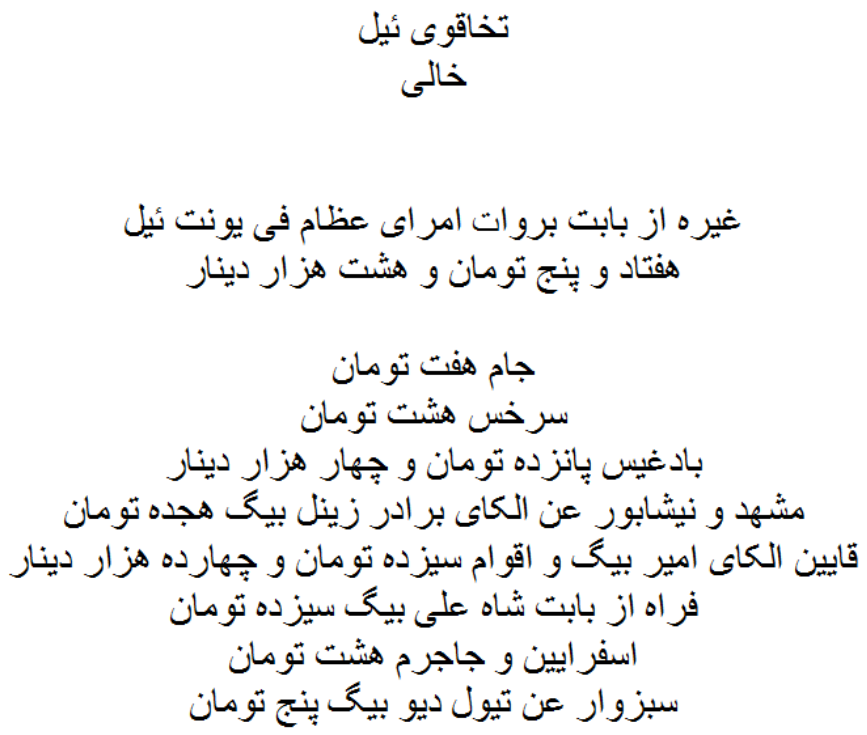

\begin{abstract}
Abbreviations
699 Tapu Tahrir Defteri: 699 Numaralı Gence Vilâyeti Tapu Tahrir Defteri H. 1001 (1593). Transcribed edition by E. Kuş. Sakarya Üniversitesi, 2003 (Unpublished M.A. Thesis).

AFT I: Khūzānī Ișfahānī, Fażlī Beg: Afżal al-tavārīkh. Persian MS Eton-Pote 278. Cambridge University Library, Cambridge.

AFT II: Khūzānī Iṣfahānī, Fażlī Beg: Afżal al-tavārīkh. Persian MS Or. 4678. The British Library, London.

AFT III: Khūzānī Ișfahānī, Fażlī Beg: Afżal al-tavārīkh. Persian MS Dd. 5.6. Old Library, Christ's College, Cambridge.

AhT: Khākī Shīrāzī, Hasan Beg: Ahsan al-tavārīkh. Persian MS Or. 1649. The British Library, London.

D. 10734: Daftar-i asbābhā-yi Shah Ismā ìl, Persian MS D. 10734. Topkap1 Palace Museum Archives. Istanbul.

E. 1071: E. 1071, Topkap1 Palace Museum Archives, Istanbul.

IVG: Iran Village Gazetteer. 22 vols. Tehran, 1345-1348 Sh./1966-1970.

Jung 3455: Aḥmad Ghulām et al.: Jung. Persian MS 3455. Majlis Library, Tehran.

SN: Ḥusām al-Dīn Idrīs Bidlīsī: Salīm-nāma. Persian MS Add. 24960. British Library, London.
\end{abstract}

\title{
References
}

\section{Primary Sources}

Ahlī Shīrāzī, Muḥammad (1344 Sh./1965): Kullīyāt-i dīvān-i Mawlānā Ahlī Shīrāzì. Ed. Ḥ. Rabbānī. Tehran.

Amīn̄ì Haravī, Șadr al-Dīn Ibrāhīm (1383 Sh./2004): Futūhạat-i Shahī. Ed. M. R. Nașīiñ. Tehran. 
Angiolello, Giovan Maria (1980): Vita e fatti del signor Ussuncassano. In: Milanesi, M. (ed.): Giovanni Battista Ramusio, Navigazioni e Viaggi. 4 vols. Vol. 3, pp. 357-420. Torino.

Anonymous (1361 Sh./1982): Tārīkh-i Qizilbāshān. Ed. H. Muhaddith. Tehran.

Anșārī Iṣfahān̄̄, Muhammad Rafī'. (1380 Sh./2001): "Dastūr al-mulūk.” In: Afshār, I. (ed.): Daftar-i tārìkh. Jild-i avval, pp. 477-651. Tehran.

Arak'el of Tabriz (2010): Book of History. Tr. G. A. Bournoutian. Costa Mesa.

Bacqué-Grammont, J.-L. (1991): Etudes turco-safavides, XVI. Quinz lettres d’Uzun Süleymân Paşa, Beylerbey du Diyâr Bekir (1533-1534). Anatolia Moderna/Yenı Anadolu. Vol. 1, pp. $135-186$.

Bacqué-Grammont, J.-L.-Adle, C. (1986): Quatre lettres de Šeref Beg de Bitlîs (1516-1520) (Etudes turco-safavides, XI). Der Islam Vol. 63, No. 1, pp. 90-118.

Barbaro, Iosafa (1980): Viaggio di Iosafa Barbaro alla Tana e nella Persia. In: Milanesi, M. (ed.): Giovanni Battista Ramusio, Navigazioni e Viaggi. 4 vols. Vol. 3, pp. 481-576. Torino.

Barkan, Ö. L. (1943): XV ve XVI'inci Asırlarda Osmanlı Imparatorluğunda Ziraî Ekonominin Hukukî ve Malî Esasları. Vol. 1: Kanunlar. Istanbul.

Barkan, Ö. L. (1953-1954): H. 933-934 (M. 1527-1528) Mali Yılına ait Bütçe Örneği. İstanbul Üniversitesi İktisat Fakültesı Mecmuası Vol. 15, Nos 1-2, pp. 251-329.

Bidlīsī, Sharaf Khān (1860-1862): Sharafnāma. Ed. V. Véliaminof-Zernof. 2 vols. St. Petersburg.

Celâl-Zade Mustafa (1990): Selim-nâme. Ed. A. Uğur and M. Çuhadar. Ankara.

Chardin, Jean (1811): Voyages du Chevalier Chardin en Perse et autres lieux de l'Orient. Ed. L. Langlès. 10 vols. Paris.

Dūghlāt, Mīrzā Haydar (1996): Tarikh-i-Rashidi. A History of the Khans of Moghulistan. Ed. \& tr. W. M. Thackston. 2 vols. Cambridge, Mass.

E. 3160, Topkap1 Palace Museum Archives, Istanbul; reproduced as document 29 in Fekete (1977, p. 230).

E. 5831, Topkap1 Palace Museum Archives, Istanbul; reproduced as document 50, in Fekete (1977, pp. 315-316).

E. 5835, Topkap1 Palace Museum Archives, Istanbul; reproduced as documents 34 and 38 in Fekete (1977, pp. 255-258, 269-270).

E. 8349, Topkapı Palace Museum Archives, Istanbul; reproduced as document 25 in Fekete (1977, p. 260).

E. 11996, Topkapı Palace Museum Archives, Istanbul; reproduced in Bacqué-Grammont (1987, pp. 179-181).

E. 12212, Topkap1 Palace Museum Archives, Istanbul.

Fekete, L. (1977): Einführung in die persische Paläographie. 101 persische dokumente. Ed. G. Hazai. Budapest.

Feridun Bey (1265-1274 AH/1848-1858): Mecmua-yı Münşeât-ı Feridun Bey. 2 vols. Istanbul.

Gelibolulu Mustafa 'Ali (2009): Künhü'l-ahbâr. Dördüncü Rükn Osmanlı Tarihi. Facsimile edition of the MS Y/546, Türk Tarih Kurumu Kütüphanesi. Ankara.

Ghaffārī Qazvīnī, Aḥmad (1343 Sh./1964): Tārīkh-i jahān-ārā. Tehran.

Ḥāfiz Abrū, Shahāb al-Dīn 'Abd-Allāh Khvāfì (1378 Sh./1999): Jughrāfiā-yi Hāafiz Abrū. Ed. Ṣ. Sajjādī. 3 vols. Tehran.

Hiillì, Ḥasan b. Yūsif b. 'Alī al-Muțahḥar. (1410 AH/1989-1990): Nihāyat al-ihkām fì ma 'rifat alahkām. 2 vols. Qum.

Hoca Sa'dettin Efendi (1979): Tâcü't-tevârih. Ed. İ. Parmaksızoğlu. 5 vols. Ankara.

Husayn̄̄ Qum̄̄, Ahmad (1959): Calligraphers and Painters. A Treatise by Qadi Ahmad Son of Mir Munshi (Circa A. H. 1015/A. D. 1606). Tr. V. Minorsky. Washington D.C.

Ḥusayn̄̄ Qumī, Aḥmad (1359 Sh./1980): Gulistān-i hunar. Ed. A. S. Khvānsārī. Tehran. 
Ḥusaynī Qumī, Aḥmad (1383 Sh./2004): Khulāṣat al-tavārīkh. Ed. I. Ishrāqī. Tehran.

İlhan, M. M. (1977): The 1518 Ottoman Cadastral Survey of the Sancak of Amid. University of Manchester (Unpublished Doctoral Thesis).

Jodogne, P. (1980): La « Vita del Sofì » di Giovanni Rota. Edizione critica. In: Forti, F. (ed.): Studi in onore di Raffaele Spongano. Bologna, pp. 215-234.

Kaempfer, Engelbert (1712): Amoenitatum Exoticarum Politico-Physico-Medicarum Fasciculi V. Lemgoviae.

Khunjī Ișfahānī, Fażl-Allāh (1992): Tārīkh-i 'ālam-ārāayi Amīnī. Ed. J. E. Woods. London.

Khvāndmīr, Ghīyāth al-Dīn (1333 Sh./1954): Tārīkh-i habīb al-siyar fì akhbār-i afrād-i bashar. Ed. M. Dabīr-Siyāqī. 4 vols. Tehran.

Lāhījī, 'Ali (1353 Sh./1974): Tārīkh-i khānī. Ed. M. Sutūda. Tehran.

Lütfi Paşa (1341 AH/1923): Tevârih-ı âl-l 'Osmân. Ed. 'Â. Efendi. Istanbul.

Martin, B. G. (1965): Seven Șafawid Documents from Azerbayjan. In: Stern, S. M. (ed.): Documents from Islamic Chanceries. Oxford, pp. 171-206.

Matrakçı, Nasüh's-Silahi (1976): Beyan-ı Menazil-ı Sefer-ı 'Irakeyn-ı Sultan Süleyman Han. Ed. H. G. Yurdaydın. Ankara.

[Mīrzā Samī'ā] (1943): Tadhkirat al-Mulūk. A Manual of Șafavid Administration (Circa 1137/1725). Tr. V. Minorsky. London.

Nașīrī, 'Alī-Naqī. (1371 Sh./1992): Alqāb u mavājib-i dawra-yi salāțīn-i Safavīyya. Ed. Y. Rahīinlū. Mashhad.

Nuvīdī Shīrāzī, 'Abdī Beg (1369 Sh./1990): Takmilat al-akhbār. Ed. 'A. Ḥ. Navā’̀̄. Tehran.

Ovanes of Erciyes (1971): Khronika Ovanesa Ardzhishesi (XVI v.). In: Zulalian, M. K.: Armenia $v$ pervou polovine XVI $v$. Moscow, pp. 113-117.

Papazian, A. D. (1956-1968): Persidski dokumenty Matenadaranan. 2 vols in 3. Erevan.

Puturidze, V. S. (1955): Gruzino-Persidskii istorichski dokumenty. Tbilisi.

Qazvīn̄i, Būdāq Munshī (1999): Javāhir al-akhbār. Ed. M. R. Nașīī and K. Haneda. Tokyo.

[Romano, Francesco] (1980): Viaggio d'un mercante che fu nella Persia. In: Milanesi, M. (ed.): Giovanni Battista Ramusio, Navigazioni e viaggi. 4 vols. Torino, Vol. 3, pp. 421-479.

Rūmlū, Ḥasan (1383 Sh./2004): Ahsan al-tavārīkh. Ed. 'A. Ḥ. Navā’̀̄. Tehran.

Samarqandī, Kamāl al-Dīn 'Abd al-Razzāq (1935-1939): Maṭla'-i sa'dayn u majma'-i baḥrayn. Ed. M. Shafí'. 2 vols. in 3. Lahore.

Sayfì Qazvīn̄i, Yahyā (1386 Sh./2007): Lubb al-tavārīkh. Ed. H. Muhaddith. Tehran.

Simões, Gil (1898): Do caminho que fizeram e do que passarm os embaixadores que foram ao Xeque Ismael, e o presente que leuaram, e da reposta que trouxeram. In: de Bulhão Pato, R. A. (ed.): Cartas de Affonso de Albuquerque. 8 vols. Lisbon, Vol. 2, pp. 233-254.

Şükrî Bitlisî (1997): Selim-nâme. Ed. M. Arğunşah. Kayseri.

Tenreiro, António (1923): Itinerário de Antonio Tenrreyro, Caualeyro da Ordem de Christo, em que se contem como da India vêo por terra a estes Reynos de Portugal. In: Baião, A. (ed.): Itinerários da Índia a Portugal por terra. Coimbra.

TTihrān̄̄, Abū Bakr (1962-1964): Kitāb-i Diyārbakrīyya. Ed. N. Lugal and F. Sümer. Ankara.

Ṭūsī, Muhammad b. Hasan. (1387-1391 AH/1967-1972): Al-Mabsūt fì fiqh al-imāmīyya. Ed. M. T. Kashfĩ. 8 vols. Tehran.

Yazdī, Sharaf al-Dīn 'Alī (1387 Sh./2008): Zafarnāma. Ed. S. M. Mīr Ṣādiq and 'A. Ḥ. Navā'ī. Tehran. 


\section{Secondary Sources}

Ardiçoğlu, N. (1964): Harput Tarihi. Istanbul.

Aubin, J. (1959): Šah Ismail et les notables de l'Iraq persan (Etudes safavides, I.). Journal of the Economic and Social History of the Orient Vol. 2, No. 1, pp. 37-81.

Aubin, J. (1984): Révolution chiite et conservatisme. Les soufis de Lâhejân, 1500-1514 (Etudes safavides, II.). Moyen Orient \& Océan Indian Vol. 1, pp. 1-40.

Aubin, J. (1986): Chiffres de population urbaine en Iran occidental autour de 1500. Moyen Orient \& Océan Indien Vol. 3, pp. 37-54.

Aubin, J. (1988): L'avènement des Safavides reconsidéré (Etudes safavides, III). Moyen Orient \& Océan Indien Vol. 5, pp. 1-130.

Aubin, J. (1994): La politique orientale de Selim I ${ }^{\text {er }}$ In: Curiel, R. -Gyselen, R. (eds): Res Orientalis, Vol. 6: Itinéraires d'Orient. Hommages à Claude Cahen, pp. 197-216. Bures-SurYvette.

Aubin, J. (1995): Chroniques persanes et relations italiennes. Notes sur les sources narratives du règne de Šâh Esmâ'il I ${ }^{\mathrm{er}}$. Studia Iranica Vol. 24, No. 2, pp. 247-259.

Aydın, N. (2011): Diyarbakir ve Mirdasiler Tarihi. Piran, Gil, Çermog, Pale. Istanbul.

Bacqué-Grammont, J.-L. (1987): Les Ottomans, les Safavides et leurs voisins. Contributions à l'histoire des relations internationales dans l'Orient islamique de 1514 à 1524. Istanbul.

Bacqué-Grammont, J.-L. (1993): Documents safavides et archives de Turquie. In: Calmard, J. (ed.): Etudes safavides. Paris, pp. 13-16.

Barkan, Ö. L. (1957): Essai sur les données statistiques des registres de recensement dans l'Empire ottoman aux $\mathrm{XV}^{\mathrm{e}}$ et $\mathrm{XVI}^{\mathrm{e}}$ siècles. Journal of the Economic and Social History of the Orient Vol. 1, No. 1, pp. 9-36.

Bartusis, M. C. (2013): Land and Privilege in Byzantium. The Institution of Pronoia. Cambridge.

Baykara, T. (1988): Anadolu'nun Tarihî Coğrafyasına Giriş, I. Anadolu’nun İdarî Taksimatı. Ankara.

Beik, W. (1985): Absolutism and Society in Seventeenth-Century France. State Power and Provincial Aristocracy in Languedoc. Cambridge.

Beldiceanu, N. (1980): Le timar dans l'État Ottoman (début XIVe-début XVI siècle). Wiesbaden.

Bizbirlik, A. (1999): 16. Yüzyılın Ortalarında Atak Sancağı ve Sancak Beyleri Üzerine Notlar. Ege Üniversitesi Edebiyat Fakültesi Tarih Bölümü Tarih İncelemeler Dergisi Vol. 14, Nos 1-2, pp. 109-133.

Collins, J. B. (1988): Fiscal Limits of Absolutism. Direct Taxation in Early Seventeenth-Century France. Berkeley.

Dickson, M. B. (1958): Sháh Țahmásb and the Úzbeks. The Duel for Khurásán with 'Ubayd Khán, 930-946/1524-1540. Princeton University (Unpublished Ph.D. Dissertation).

Dickson, M. B. (1963): Uzbek Dynastic Theory in the Sixteenth Century. In: Ghafurova, B. (ed.): Trudy dvadtsat'piatogo mezhdunarodnogo kongressa vostokvedov (Moskva 9-16 Avgust 1960). 4 vols. Moscow, Vol. 3, pp. 208-216.

Doerfer, G. (1963-1975): Türkische und mongolische Elemente im Neupersischen. 4 vols. Wiesbaden.

Emecen, F. M. (2011): Zamanın Iskenderi, Şarkın Fatihi. Yavuz Sultan Selim. Istanbul.

Fleischer, C. H. (2011): Companions to a King Errant. Bābur and His Lieutenants to the Conquest of Kabul. In: Binbaş, İ. E. - Kılıç-Schubel, N. (eds): Horizons of the World. Festschrift for Isenbike Togan. Istanbul, pp. 545-566.

Floor, W. (2000): The Secular Judicial System in Safavid Persia. Studia Iranica Vol. 29, No. 1, pp. $9-60$. 
Fragner, B. (1986): Social and Internal Economic Affairs. In: Jackson, P.-Lockhart, L. (eds): The Cambridge History of Iran. Vol. 6: The Timurid and Safavid Periods. Cambridge, pp. 491567.

Gökbilgin, M. T. (1951): XVI. Asır Başlaraında Osmanlı Devleti Hizmetindeki Akkoyunlu Ümerâs1. Türkiyat Mecmuasi Vol. 9, pp. 35-46.

Goldstone, J. A. (1991): Revolution and Rebellion in the Early Modern World. Berkeley.

Göyünç, N. (1969a): Diyarbakir Beylerbeyliği’nın İlk İdâri Taksimatı. İstanbul Üniversitesi Edebiyat Fakültesi Tarih Dergisi Vol. 23, pp. 23-34.

Göyünç, N. (1969b): XVI. Yüzyılda Mardin Sancă̆ı. Istanbul.

Ḥā’irī, ‘A. Ḥ. (1348 Sh./1969-1970): Fihrist-i nuskhahā-yi khatți-i Majlis-i Shawrā-yi Millī. Vol. 10 in 3 Pts. Tehran.

Howard, D. A. (1987): The Ottoman Timar System and Its Transformation, 1563-1656. Indiana University (Unpublished Ph.D. Dissertation).

Inalcik, H. (2006): Autonomous Enclaves in Islamic States. Temlîks, Soyurghals, Yurdluk-Ocakluks, Malikâne-Mukata'as and Awqaf. In: Pfeiffer, J.-Quinn, S. A. (eds): History and Historiography of Post-Mongol Central Asia and the Middle East. Studies in Honor of John E. Woods. Wiesbaden, pp. 112-134.

Inalcik, H. et al. (1994): An Economic and Social History of the Ottoman Empire. 2 vols. Cambridge.

Kılıç, O. (1999): XVI. Yüzyılda Adılcevaz ve Ahlat (1534-1605). Ankara.

Kırzıoğlu, M. F. (1979): .1593 (H. 1001) Y1lı Osmanlı Vilâyet Tahrir Defteri'nde Anılan GenceKarabağ Sancakları "Ulus" ve "Oymak”ları. Atatürk Üniversitesi Edebiyat Fakültesi Araştırma Dergisi Vol. 10, pp. 199-222.

Kırzıoğlu, M. F. (1993): Osmanlılar'ın Kafkas-Elleri'ni Fethi (1451-1590). Ankara.

Lambton, A. K. S. (1987): Qajar Persia. Eleven Studies. London.

Lambton, A. K. S. (1991): Landlord and Peasant in Persia. A Study of Land Tenure and Land Revenue Administration. London.

Lambton, A. K. S. (2000): Tiyūl. In: Encyclopaedia of Islam, second edition, Vol. 10, pp. 550-551.

Minorsky, V. (1927): Tiyūl. In: Encyclopaedia of Islam, first edition, Vol. 8, pp. 799-800.

Minorsky, V. (1939): A Soyurghal of Qasim b. Jahangir Aq-qoyunlu (903/1498). Bulletin of the School of Oriental Studies Vol. 9, No. 4, pp. 927-960.

Minorsky, V. (1955): The Aq-Qoyunlu and Land Reforms (Turkmenica, 11). Bulletin of the School of Oriental and African Studies Vol. 17, pp. 449-462.

Miroğlu, İ. (1975): XVI. Yüzyılda Bayburt Sancağı. Istanbul.

Miroğlu, İ. (1990): Kemah Sancağ ve Erzincan Kazası (1520-1566). Ankara.

Muntazirīī, Husayn-'Alī. (1365 Sh./1986): Risāla fi 'l-ihtikār wa'l- tas 'īr. Tehran.

Öz, T. (1938-1940): Topkapı Sarayı Müzesi Arşivi Kılavuzu. 2 vols. Istanbul.

Paydaş, K. (2004): Ak-Koyunlu Ahmed Bey ve Onun İdarî Sistemini Ak-Koyunlu Devleti'nde Uygulama Çabası. Ankara Üniversitesi Dil ve Tarih-Coğrafya Fakültesı Tarih Bölümü Tarih Araştırmaları Dergisi Vol. 23, pp. 205-212.

Petrushevskii, I. P. (1949): Ocherkii po istorii feodal'nyx otnoshenii v Azerbaidzhane i Armenii $v X V I$-nachale $X I X v$. Leningrad.

Posch, W. (2013): Osmanisch-safavidische Beziehungen 1545-1550. Der Fall Alkâs Mîrzâ. Vienna.

Rabino, H. L. (1945): Coins, Medals, and Seals of the Shâhs of Iran, 1500-1941. Hartford.

Riyāḥī, M. A. (1372 Sh./1993): Tārīkh-i Khuy. Tehran.

Sarwar, G. (1939): History of Shah Ismā 'ìl Safawī. Aligarh.

Savory, R. M. (1965): Consolidation of Șafawid Power in Persia. Der Islam Vol. 41, pp. 71-94.

Seçkin, B. S. (2006): Başlangıçtan Günümüze Siirt Tarihi. Istanbul. 
Sharīf, 'A. A. (1352 Sh./1973): Laghv-i tiyūl u tiyūldārī. Barrasīhā-yi Tārīkhī Vol. 8, Nos 1-2, pp. $79-85$.

Shukurov, R. M. (1993): The Campaign of Shaykh Djunayd Șafawī against Trebizond (1456 $\mathrm{AD} / 860$ H). Byzantine and Modern Greek Studies Vol. 17, No. 1, pp. 127-140.

Shukurov, R. M. (2001): Velikie Komneny i Vostok (1204-1461). St. Petersburg.

Smith, R. B. (1970): The First Age of the Portuguese Embassies, Navigations and Peregrinations in Persia (1507-1524). Bethesda, Md.

Subtelny, M. E. (2007): Timurids in Transition. Turko-Persian Politics and Acculturation in Medieval Iran. Leiden.

Sümer, F. (1992): Çepniler. Anadolu'daki Türk Yerleşmesinde Önemli Rol Oynayan Bir Ŏguz Bo$y u$. Istanbul.

Szuppe, M. (1992): Entre Timourides, Uzbeks et Safavides. Questions d'histoire politique et sociale de Hérat dans la première moitié du XVI siècle. Paris (Studia Iranica Cahier 12).

Ṭabātabā'̄i, Ḥ. M. (1352 Sh./1973): Farmānhāa-yi Turkmanān-i Qarāquyūnlū u Āqquyūnlū. Qum.

Tekindağ, Ş. (1968): Yeni Kaynak ve Vesîkaların Işiğı Altında Yavuz Sultan Selim'in İran Seferi. İstanbul Üniversitesi Edebiyat Fakültesi Tarih Dergisi Vol. 17, No. 1, pp. 49-78.

Tezcan, B. (2000): The Development of the Use of Kurdistan as a Geographical Description and the Incorporation of this Region into the Ottoman Empire in the 16th Century. In: Çiçek, K. (ed.): The Great Ottoman-Turkish Civilization. 4 vols. Ankara, Vol. 3, pp. 540-553.

Tezcan, B. (2010): The Second Ottoman Empire. Political and Social Transformation in the Early Modern World. Cambridge.

Tîgrîs, A. (2008): Licê. Stockholm.

Uluçay, Ç. (1954a): Yavuz Sultan Selim Nasıl Padişah Oldu? [pt. 1]. İstanbul Üniversitesi Edebiyat Fakültesi Tarih Dergisi Vol. 6, No. 9, pp. 53-90.

Uluçay, Ç. (1954b): Yavuz Sultan Selim Nasıl Padişah Oldu? [pt. 2]. İstanbul Üniversitesi Edebiyat Fakültesi Tarih Dergisi Vol. 7, No. 10, pp. 117-142.

Uluçay, Ç. (1955): Yavuz Sultan Selim Nasıl Padişah Oldu? [pt. 3]. İstanbul Üniversitesi Edebiyat Fakültesi Tarih Dergisi Vol. 8, Nos 11-12, pp. 185-200.

Ünal, M. A. (1989): XVI. Yüzyılda Harput Sancağı (1518-1566). Ankara.

Ünal, M. A. (1999a): XVI. Yüzyılda Çemişgezek Sancağı. Ankara.

Ünal, M. A. (1999b): XVI. Ve XVII. Yüzylllarda Diyarbakir Eyaletine Tâbi Sancakların İdari Statüleri. In: idem: Osmanl Devri Üzerine Makaleler-Araştırmalar. Isparta, pp. 170-178.

Ünal, M. A. (1999c): XVI. Yüzyılda Palu Hükümeti. In: idem: Osmanlı Devri Üzerine MakalelerAraştırmalar. Isparta, pp. 211-234.

Van Bruinessen, M. (1988): The Ottoman Conquest of Diyarbakir and the Administrative Organization of the Province in the 16th and 17th Centuries. In: Van Bruinessen, M.-Boeschoten, H. (eds): Evliya Çelebi in Diyarbakir. The Relevant Section of the Seyahatname. Leiden, pp. $13-63$.

Woods, J. E. (1999): The Aqquyunlu Clan, Confederation, Empire. Salt Lake City.

Yamaguchi, A. (2012): Shah Ṭahmāsp's Kurdish Policy. Studia Iranica Vol. 41, No. 1, pp. $101-$ 132.

Yinanç, R. (1989): Dulkadir Beyliği. Ankara.

Zulalian, M. K. (1971): Armenia v pervol̆ polovine XVI v. Moscow. 